\title{
Evaluating Stratified Substrates Effect on Containerized Crop Growth under Varied Irrigation Strategies
}

\author{
Kristopher S. Criscione and Jeb S. Fields \\ Hammond Research Station, Louisiana State University Agricultural Center, \\ 21549 Old Covington Hwy., Hammond, LA 70403
}

Jim S. Owen Jr. Application Technology Research Unit, 1680 Madison Avenue, Wooster, $\mathrm{OH} 44691$

\section{Lisa Fultz \\ Louisiana State University AgCenter, School of Plant, Soil, and Environmental Science, 310 Sturgis Hall, Baton Rouge, LA 70803}

\section{Edward Bush}

Louisiana State University, School of Plant, Soil, and Environmental Science, 257 J.C. Miller Hall, Baton Rouge, LA 70803

Additional index words. coconut coir, cyclic, Loropetalum chinensis 'Ruby', pine bark, sphagnum peat, soilless, water efficiencies

Abstract. Growers rely on soilless substrates to provide sufficient water and nutrients to containerized crops. Traditional bark-based substrates are engineered to have relatively low water-holding capabilities, which can lead to nonuniform rewetting patterns and inefficient usage of water resources. Engineering substrates to redistribute water dynamics and maximize aeration within the container may improve water resource efficiencies. The goal of this study was to evaluate whether more efficient irrigation schedules can be used when stratifying unique substrates within a container for added crop water and nutrient efficiency. Loropetalum chinense 'Ruby' liners were planted and grown in a conventional pine bark substrate or one of three stratified substrate treatments, including a bark:peat, bark:coir, or fine bark layered on top of a coarse bark. The crops were grown under four different irrigation schedules, including single daily application, single application at deficit levels, cyclic application, or cyclic at deficit schedules. Stratified substrates improved crop growth, quality, and yield when compared with plants grown in conventional bark in the single application irrigation treatment. Measured at final harvest, substrates positively influenced plant growth index $(P<0.0001)$, whereas irrigation scheduling alone had no effect $(P=0.6321)$. There was a strong interaction between substrate and irrigation schedules on $\Delta$ growth index $(P=0.0141)$. There were strong substrate effects on shoot dry weight $(P=0.0060)$, root dry weight $(P=0.0342)$, and growth index $(P=0.0040)$. The stratified bark:coir treatment outgrew all other substrate treatments. In addition, within all irrigation treatments, plants grown with the stratified bark:coir substrate had the highest survival ratings among the other substrate treatments, whereas the conventional bark had the lowest survival rates. Substrate and irrigation had an effect on nitrogen and potassium leachate concentrations levels $(P=0.0107$ and $P=0.0004$, respectively). Evaluation of microbial communities showed that substrate $(P=0.0010)$ and the stratified layer $(P=0.0010)$ had strong influences on the type of community present and the relative abundance in the treatments used herein this study. Specifically, within cyclic scheduling, bark:peat actinomycete populations were significantly greater than other substrate treatments. Furthermore, under deficit irrigation, stratified substrate systems were able to mitigate crop water stress. The results indicate that when crops such as the Loropetalum are grown in the stratified system, crop growth can be sustained when drought conditions are present. This is possible by providing adequate water availability even under low water inputs until subsequent irrigations during the fragile establishment period, when compared with using traditional bark-based substrates.

Plant nurseries are the primary producer for ornamental crop production in which plants are grown to quickly generate a salable crop (Dumroese et al., 2012). Most nurseries consist of open-air production systems, which require intensive management practices to run efficiently, maintain profitability, and produce aesthetically superior crops (Avent, 2003).
This balance of needed intensive management and profitably requires nursery growers to sustainably and effectively use resources, such as water, substrates, and fertilizer, to persevere in the industry.

Agriculture is the primary consumer of Earth's freshwater resources, with an estimated $70 \%$ of all freshwater withdrawals being used for agricultural production (Calzadilla et al., 2010). Research has shown that many aquifers, groundwater, and surface waters are being depleted, with potential longterm consequences due to large agricultural water consumptions (Folger, 2017; Gray and Merzdorf, 2019; Kirkpatrick et al., 2009; Steward and Allen, 2016; Thomas and Famiglietti, 2019). Concurrently, agricultural production and sales have been increasing in the past two decades, where in 2002, all agriculture products sold were $\approx \$ 200$ billion and increased to \$389 billion in 2017 (U.S. Department of Agriculture, 2019). To sustain this growing demand, more water is required to meet increasing production needs (Morison et al., 2008). In 2009, horticultural specialty crops and nursery stock generated $\$ 15.9$ billion, and increased to $\$ 18.3$ billion in 2019 (U.S. Department of Agriculture, 2020). This industry accounts for $\approx 4.7 \%$ of all the agricultural crop sales within the United States (U.S. Department of Agriculture, 2020) and where container production is abundant, water for irrigation is often restricted, limited, or both (Beeson, 2006). Fulcher and Fernandez (2013a) estimated that container nurseries use upward of $177 \mathrm{~m}^{3} / \mathrm{ha} / \mathrm{d}$ for irrigation. Accordingly, a growing proportion of nurseries have become conscious of their environmental impact and currently implement Best Management Practices to their production practices and thus, improving environmental stewardship among the industry (Mack et al., 2017).

Sustainability, especially in horticulture, has grown in popularity (Dennis et al., 2010), as consumers have become concerned where their products are derived from and how they are produced. Krug et al. (2008) stated that implementing sustainable greenhouse production practices (recycling containers, controlled release fertilizers, alternative energy sources, biological controls, composting, etc.; Dennis et al., 2010; Lopez et al., 2008) may create a "niche market," attracting consumers that shop at locations that have adopted sustainable habits. In addition, consumers may be willing to pay top price for sustainable products (Krug et al., 2008) or if produced locally. Research has shown a variety of opportunities to increase production sustainability among container nurseries, especially with regard to a decrease in plastic use using alternative containers (Nambuthiri et al., 2015), plant water use (Fields et al., 2018), reduction in peat materials with alternative substrates (Jackson et al., 2010), decrease in water inputs via substrate engineering (Fields et al., 2017), irrigation efficiencies through strategic scheduling (Million and Yeager, 2020), and additional best management practices (Bilderback et al., 2013).

Resources are of upmost importance to nursery crop producers, as water shortages intensify and restricted sources become more abundant (Costa et al., 2007; Fulcher et al., 2016). It is becoming necessary for growers to implement more conservative water application approaches with informed irrigation scheduling used as a primary method for conservation (Million and Yeager, 2020; Yeary et al., 2016). The most basic and necessary 
practice for a grower is delivering water to crops. Excessive applications or inadequate watering can result in detrimental losses to the health and quality of the crop yield and a nursery's profitability. Optimizing irrigation applications can reduce costs by decreasing energy use, fertilizer, and labor required, speed production time through an increased harvest by decreasing plant loss (Lichtenberg et al., 2013), and reduce overall water use (Bayer et al., 2015; Million and Yeager, 2015).

Overhead irrigation is the most commonly used method to apply water to nursery containers, especially for those smaller than $26.5 \mathrm{~L}$ (Fulcher et al., 2016). Typically, nurseries will apply overhead irrigation once per day (Beeson and Haydu, 1995), either via scheduled clocks or manually by employees (van Iersel et al., 2013). Growers will often schedule irrigations predawn or early morning to ensure worker access during the day and reduce the losses of water from wind and evapotranspiration (Fulcher and Fernandez, 2013b); however, irrigating once a day may not be efficient (i.e., lower water application efficiency) or adequate to retain the needed water to meet daily evaporative demand. Irrigating once a day relies solely on the water storage/reservoir of a given container for a $24-\mathrm{h}$ period. This reservoir can become depleted, and the substrate components can become hydrophobic, preventing the ability to adequately rewet the substrate on the next irrigation. Thus, an excessive quantity of leaching from the container may occur (Lieth and Oki, 2008).

Conversely, cyclic irrigation, or irrigating the same quantity of water in smaller quantities throughout the day, was designed to irrigate crops proportional to the infiltration rate of the substrate (Lamack and Niemiera, 1993). Moreover, cyclic irrigation replenishes the water reservoir throughout the day to ensure physiological processes and subsequent growth is not limited by the water status of the crops (Warren and Bilderback, 2002). Numerous authors have reported that plant responses, such as plant height, lateral branching, increase in root exploration, root and shoot dry weight, and stem diameter are increased when cyclic irrigation is used (Ismail et al., 2007; Ruter, 1998; Taylor et al., 2013; Witcher, 2003). Furthermore, many have reported that cyclic irrigation also reduces leaching of mineral nutrients from a container and decreases the subsequent

Received for publication 6 Oct. 2021. Accepted for publication 4 Dec. 2021

Published online 1 February 2022.

This paper was written as a contributing portion of a Master of Science thesis for Kristopher S. Criscione to fulfill degree requirements.

K.S.C. is a Master's Candidate.

J.S.F. is an Assistant Professor.

J.S.O. is a Research Horticulturist.

L.F. is an Associate Professor.

E.B. is a Professor.

J.S.F. is the corresponding author. E-mail: JFields@agcenter.lsu.edu.

This is an open access article distributed under the CC BY-NC-ND license (https://creativecommons. org/licenses/by-nc-nd/4.0/). surface runoff that can lead to eutrophication of contaminated waters (Karam, 1993; Taylor et al., 2013; Witcher, 2003). It was also concluded by a few that cyclic irrigation can reduce water consumption by upward of $38 \%$ within the container (Lamack and Niemiera, 1993; Tyler et al., 1996; Yeary et al., 2016). In addition, multiple applications ensure that an amount of water not exceeding substrate capacity is added to a relatively hydrophilic substrate in which available water is present, thus minimizing channeling and supporting more "piston flow" like hydraulics within the container column (Hoskins et al., 2014a).

Deficit irrigation is also becoming more commonly implemented as a water management strategy as water becomes less available. Fulcher et al. (2016) predict that future agricultural systems will be required to increase their crop yield while consuming and applying less or lower quality water. This entails reducing the quantity of water that is irrigated to the crops based on the standard watering quantity (Fereres and Soriano, 2007). Deficit irrigation involves inducing water stress to the plant and is often used during drought-sensitive growth stages to reduce water use (Asrey et al., 2018).

Substrate management is one method that can lead to more water-efficient production practices for containerized crops. Soilless substrates were initially designed to decrease disease pressures in container production (Baker, 1957). In doing so, containerized media transitioned to substrates with improved porosity (Wilkerson, 1981) and aeration throughout the container profile (Raviv and Lieth, 2008), thus, allowing for ample drainage (Jackson et al., 2006). Pine bark has been observed to be a suitable medium for plant growth (Pokorny et al., 1986), especially in southern nurseries, and is accepted as the primary component of most soilless substrates in container production (Bilderback et al., 2013). However, high porosity may often lead to multiple irrigation applications (Majsztrik et al., 2017; Tyler et al., 1996). This results in a loss of mineral nutrients (Taylor et al., 2013), surface and groundwater contamination (Richards and Reed, 2004), and increased use of water (Mathers et al., 2005). Previous studies have shown that additions of fibers such as coconut coir and sphagnum peatmoss are excellent at increasing the water-holding capacities within a substrate (Evans et al., 1996; Londra et al., 2018). Fine particles are also effective at increasing water retention, reducing air space, and increasing container capacity (Altland et al., 2018). Bilderback et al. (2013) suggested that engineering (i.e., maintaining the balance between air space/water content ratio) soilless substrates within the container can steer the industry toward a more sustainable future (i.e., ensuring the continued availability or stability of upcoming substrate use). More recently, it has been shown that substrate engineering, altering components to modify dynamic physical properties, can ultimately reduce overall water use and production times (Fields et al., 2017).

Much of the current research surrounding soilless substrates is focused on alternative materials (Barrett et al., 2016), engineering substrate properties (Fields et al., 2018), or understanding water (Fields et al., 2020) and mineral nutrient (Hoskins et al., 2014a, 2014b) dynamics within the system. Although these are effective means and are new directions of research, innovative fine-tuning of substrate hydraulics in the form of container substrate management have recently arisen (Fields, et al., 2020). Historically, growers fill the whole container with single- or multiple-component substrates blended uniformly throughout the container. Stratification of soilless substrates involves stacking unique substrate layers within the container. Fields et al. (2021) showed the substrate system could be manipulated to conserve water and increase plant growth within the first year of establishment, while reducing fertilizer load by $20 \%$. This concept is also being used by Marble and Khamare (2020) to reduce weed germination in containers in which a coarse, dry substrate layer is placed atop conventional substrate.

Substrate stratification may allow growers to reduce their overall water use by creating desirable water retention capabilities. The current water gradient that is present within traditional substrate systems is not optimal for containerized crop production due to use as a single-heterogeneous (i.e., filled uniformly throughout the container) substrate. Moreover, traditional substrate systems may reduce plant establishment rates and overall growth due to the upper portion drying quickly (Bilderback and Fonteno, 1987) and the bottom portion becoming near saturated, reducing gas exchange (Caron et al., 1999). However, stratifying substrates may create more desirable and uniform moisture gradients throughout the entire profile rather than large gradient observed in conventional substrates.

Slowing the rate at which water is lost in the upper half of the substrate profile, while prohibiting saturated conditions in the lower half through stratifying substrates may complement root growth and correspond to diurnal evaporation/transpiration and may bring a multitude of advantages to container production. Further benefits of the stratified system may allow growers to use alternative irrigation scheduling for added water efficiency. Substrate stratification may allow nursery growers to take more advantage of cyclic irrigation timings or practice a deficit irrigation regimen, even when weather patterns do not seem favorable.

The fundamental objective of this study was to determine if substrate stratification practices can aid in increasing water resource efficiency of containerized crops while quickly producing a high-value and uniform crop. This objective is accomplished by 1) investigating the impact of stratified substrate systems on crop growth and development, and 2) assessing the interaction of substrate and irrigation. The authors hypothesized that stratifying substrate systems may allow for a reduction in irrigation volumes applied, and thus, improve water resource usage. 


\section{Materials and Methods}

Substrate preparation. Aged loblolly pine bark (Pinus taeda L.; Phillips Bark Processing Co.; Brookhaven, MS) was sourced and processed through a continuous flow screen (Model \# CF-1, Serial \# CF-217; Gilson Company Inc., Lewis Center, $\mathrm{OH}$ ) at the LSU AgCenter Hammond Research Station (Hammond, LA). The goal of the processing was to develop five unique substrates through bark fractioning and amending with different fibrous materials. The continuous-flow screen was fitted with a $6.3-\mathrm{mm}$ aperture screen, set to $569 \mathrm{rpm}$, and screen level was maintained at $5^{\circ}$ inclined slope throughout the experiment. Two receptacles were placed under the sieve to collect particles that passed through the screen (unders) and to collect particles that did not pass through and were discharged (overs). The bark particles were processed through the screen at a rate of $0.012 \mathrm{~m}^{3} / \mathrm{min}$, and the process was stopped every $10 \mathrm{~min}$ to remove debris from the screen. The screened particle was composed of a 3 to 5 ratio unders:overs by volume (L) and a 4 to 5 ratio unders:overs by dry weight $(\mathrm{kg})$. This process was continued until a total of $0.84 \mathrm{~m}^{3}$ coarse bark particles (overs) and $0.28 \mathrm{~m}^{3}$ of fine bark particles (unders) were collected to account for every stratified lower strata (coarse bark) and the stratified treatment fine bark layered above coarse bark (FB). In addition, $0.57 \mathrm{~m}^{3}$ of unscreened pine bark was collected (control substrate). Two additional substrates were prepared by blending $0.3 \mathrm{~m}^{3}$ conventional pine bark with either hydrated coconut coir (Jolly Gardener, Gainesville, VA) or hydrated Sphagnum peatmoss (Premier Tech, Quebec, CA) at 3:1 by volume ratio. Each substrate was then amended with $2.67 \mathrm{~kg} / \mathrm{m}^{3}$ dolomitic lime (Lime-Rite Pelletized Dolomitic Lime, Roswell, GA) and 0.89 $\mathrm{kg} / \mathrm{m}^{3}$ micronutrients (Micromax G90505; ICL Specialty Fertilizer, Dublin, $\mathrm{OH}$ ) and blended in a ribbon soil mixer for $10 \mathrm{~min}$.

Physical properties. Static physical properties were measured via porometer analysis of three replicates as described by Fonteno and Harden (2010) to determine air space (AS), container capacity (CC), total porosity (TP), and bulk density $\left(\mathrm{D}_{\mathrm{b}}\right)$. Particle size distribution of each substrate was then evaluated by passing three $100-\mathrm{g}$ dry replicates of each substrate through a column of 6.30-, 2.00-, 0.71-, 0.50-, $0.25-$, and $0.11-\mathrm{mm}$ sieves, with a pan at the bottom. Each sample was agitated for exactly 5 min with a Ro-Tap shaker (Rx-29; W.S. Tyler, Mentor, $\mathrm{OH}$ ), and the particles were allowed to pass through the column until further movement was restricted, due to aperture blockage. Particles remaining on each sieve were weighed and compiled into four size classifications: extra large $(>6.3 \mathrm{~mm})$, large $(2.00-6.3 \mathrm{~mm})$, medium $(2.00-0.71 \mathrm{~mm})$, and fine $(<0.71 \mathrm{~mm})$.

Stratified substrates. On 9 June 2020, 224 8.52-L containers (\#2 C1000 Blow MoldedClassic Line; Nursery Supplies, Kissimmee, FL) were filled with one of four substrate treatments. The control treatment consisted of unscreened conventional pine bark (CTL). The remaining three substrate treatments were stratified, wherein the bottom half of the container was filled with coarse bark (overs on a $6.3-\mathrm{mm}$ screen). Each substrate was hydrated before blending to ensure the full expansion of individual components. The top strata was filled with either fine bark park particles (unders from 6.3-mm screen; FB), unscreened bark:peatmoss blend (BP) or unscreened bark:coconut coir blend $(\mathrm{BC})$. Each strata or layer was $\approx 11.5 \mathrm{~cm}$ in height as controlled by ensuring the lower strata was the proper height before filling with the upper strata. After all 224 containers were filled with the corresponding substrate treatments, a 5.6-cm landscape liner of Loropetalum chinensis 'Ruby' (Liner Source, Inc., Eustis, FL) was planted in each container. Each container was then top-dressed with $0.8 \times(53.6 \mathrm{~g})$ of the medium-high recommended rate of $18.0 \mathrm{~N}-6.0 \mathrm{P}_{2} \mathrm{O}_{5}-12.0 \mathrm{~K}_{2} \mathrm{O}$ controlled release, slow-start fertilizer (Osmocote; 1- to 2-month temperature depending; ICL Specialty Fertilizers; Dublin, OH). Experimental units were then moved to an open-air nursery simulation gravel pad and uniform overhead irrigation was applied daily for $6 \mathrm{~d}$ to promote root establishment.

Irrigation scheduling. After this establishment period, the replicates were split into different irrigation treatments. There were four different irrigation treatments, split into two blocks following a randomized-block design (two blocks $\times$ four irrigation treatments $=$ 8 total blocks). Each block contained seven random replicates of each substrate treatment ( 7 replicates $\times 4$ substrate treatments $=28$ total experimental units) spaced uniformly throughout the block. The four irrigation treatments were a single application per day (SA), a single application per day deficit irrigation (SD), which was $0.75 \times$ of SA; a cyclic irrigation treatment (CA), which consisted of equivalent volume of water as SA but divided evenly into three irrigations daily $(0700$, 1030, and $1400 \mathrm{hr}$ daily); and finally a cyclic deficit (CD) irrigation that irrigated at $0.75 \times$ the rate of each $\mathrm{CA}$ cycle. Irrigation timing was adjusted over the study based on leaching fractions in the SA irrigation zones. As adjustments were made to target a leaching fraction of $20 \%, \mathrm{SA}, \mathrm{SD}$, and $\mathrm{CD}$ were adjusted with $\mathrm{CA}$ receiving equal to $\mathrm{SA}$, and both $\mathrm{SD}$ and $\mathrm{CD}$ receiving $0.75 \times$.

Growth and fertility measurements. Growth indices [(plant height + widest width + perpendicular width)/3] were taken approximately every $15 \pm 1 \mathrm{~d}$ of three randomly selected plants of each treatment in each block. Each week, three random plants were chosen per substrate treatment in every irrigation block and were recorded for growth indexes with exception of the initiation of the study, where every plant was measured.

Substrate fertility was measured via pourthrough analysis (LeBude and Bilderback, 2009) approximately every $30 \mathrm{~d}$ on three random replicates of each substrate treatment in every block. Wherein, plants were irrigated to effective container capacity (maximum water holding capacity in practice), allowed to equilibrate, and $500 \mathrm{~mL}$ of deionized water was applied to displace pore-water. The displaced pore-water samples were analyzed for electrical conductivity (EC) and $\mathrm{pH}$ with a portable probe (GroLine HI 9814; Hanna Instruments, Woonsocket, RI). Samples collected on 30 and $120 \mathrm{~d}$ after initiation (DAI) were filtered with a $0.45-\mu \mathrm{m}$ syringe filter and mineral nutrient species were analyzed at time of microbial analysis using a dual ion chromatograph (Dionex ICS-6000; ThermoFisher Sci, Waltham, MA) at the U.S. Department of Agriculture-Agricultural Research Service Application Technology Research Unit, Wooster, $\mathrm{OH}$.

Microbial communities. Identification of microbial communities was assessed to examine if reorganization of substrate hydraulics creates an apparent differential in substrate microecosystem composition within a singular container profile. To determine microbial community structure, $\approx 115$ DAI, a $10 \times 2.5$ $\mathrm{cm}$ window was cut into the east side of three randomly selected replicates of every treatment. Substrate samples from each strata were collected and analyzed by using the fatty acid methyl ester analysis (FAMEs) as biomarkers described by Quideau et al. (2016). The FAME peaks were analyzed using identification software (MIDI; Microbial ID, Inc., Newark, DE) on a gas chromatograph (7890B; Agilent, Santa Clara, CA). Using a 19:0 standard, the concentration of FAMEs (nmol. $\mathrm{g}^{-1}$ substrate) was computed. Relative abundance was determined by dividing absolute abundance of each FAME by the total summation of identified FAMEs for each sample. Biomarkers included 17:0 10-methyl, 18:0 10methyl, TBSA, 16:0 10-methyl for actinomycetes, 16:1 $\omega 5 \mathrm{c}$ for arbuscular mycorrhizae fungi, 18:3 $\omega 6 \mathrm{c}(6,9,12), 18: 1 \omega 9 \mathrm{c}, 18: 2 \omega 6 \mathrm{c}$, $20: 1 \omega 9 \mathrm{c}$ for fungi, 16:1 $\omega 9 \mathrm{c}, 16: 1 \omega 7 \mathrm{c}, 17: 0$ cyclo, 19:0 cyclo $\omega 6 \mathrm{c}, 18: 1 \omega 7 \mathrm{c}, 18: 1 \omega 5 \mathrm{c}$, $19: 1 \omega 6 \mathrm{c}$ for gram-negative bacteria (Gram-), 14:0 iso, 15:0 iso, 037: 15:0 anteiso, 16:0 iso, 16:0 anteiso, 17:0 iso, 17:0 anteiso, $17: 1 \omega 9 \mathrm{c}, 18: 0$ for gram-positive bacteria (Gram+), 20:3 $\omega 6,9,12 \mathrm{c}, 23: 2 \omega 6,9 \mathrm{c}, 20: 4$ $\omega 6,9,12,15 \mathrm{c}$ for protozoa, and 22:0, 23:0, 24:0 for eukaryotes (Frostegård et al., 1993; Laczko et al., 1997; Madan et al., 2002; Morgan and Winstanley, 1997; O'Leary and Wilkinson, 1988; Paul and Clark, 1988; Ratledge and Wilkinson, 1988; White et al., 1996; Zelles, 1997, 1999; Zelles and Bai, 1994).

Weather. The summer of 2020 saw multiple hurricanes projected to impact southern Louisiana. In preparation for these storms, plants were briefly $(<5 \mathrm{~d})$ moved from the simulated nursery to a protected area and moved back after threat of the hurricanes had passed. Experimental units were moved three times in advance of Hurricanes Laura, Delta, and Zeta. Data were derived from the National Centers for Environmental Information and National Oceanic and Atmospheric Administration (NCEI and NOAA, respectively), as shown in Fig. 1.

Harvest. Photographs were taken of representative samples of shoots and roots in each 


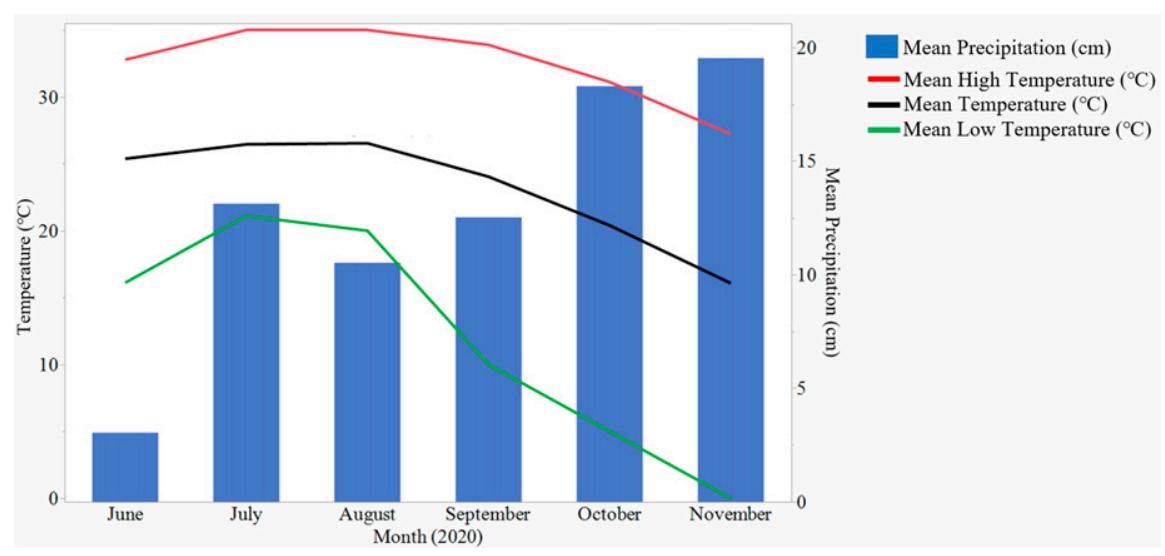

Fig. 1. Weather data of Hammond, LA, illustrating the mean, high, and low temperature in $\left({ }^{\circ} \mathrm{C}\right)$, as well as the mean precipitation in $(\mathrm{cm})$ within the months of the duration of the study (July 2020-Nov. 2020). Data were derived from National Centers for Environmental Information and National Oceanic and Atmospheric Association.

treatment on 151 DAI. The shoots and roots of every plant were assessed for subjective quality ratings. Relative subjective ratings ranged from 1 to $5(1=$ poorest growth; $5=$ best possible plant in this study). Afterward, the roots were separated from the shoots. Roots were then washed of substrate particles. The root and shoot tissues were normalized for mass by drying at $22.7^{\circ} \mathrm{C}$ for $7 \mathrm{~d}$ and then weighed. Foliar nutrition of dried foliage from three plants per treatment was then analyzed by the Louisiana State University Agricultural Center Soil Testing and Plant Analysis Laboratory (Baton Rouge, LA) by using inductively coupled plasma methods and a LECO CN Analyzer. Leaf area was measured destructively by removing and counting each leaf of three replicates per treatment and placing it on a leaf area meter (LI-3100Cl; LICOR, Lincoln, NE). Leaf area index (LAI) was then calculated by dividing the total leaf area by the area of the substrate surface $\left(519.29 \mathrm{~cm}^{2}\right)$.

Data analysis. The 16 individual treatments were analyzed as a completely randomized multifactorial. The data presented in tables and figures with associated statistics were analyzed in JMP Pro (15.1.0; SAS Institute, Inc., Cary, NC) using Tukey's honestly significant difference test $(\alpha=0.05)$ to separate means across five substrates (conventional bark, fine bark, bark:peat, bark:coir, and coarse bark; Table 1), crop responses across all substrate and irrigation treatments, and foliar nutrition. Analysis of variance was further used to determine any statistically significant differences between the means of the substrate static physical properties, particle size fractions based on dry mass, crop responses, foliar nutrition, leachate analysis, and microbial communities. In addition, standard error was calculated using JMP Pro (15.1.0) to determine differences from the mean of the samples. Microbial community composition principal coordinate analysis was completed by calculating the relative abundance of FAMEs using the vegan (Oksanen et al., 2020) package in R (R-Core Team, 2020). Ordination plots were generated to examine variances between substrate microbial communities among varying substrate and irrigation treatments. In addition, using the envfit function, the authors determined the maximum correlation across microbe community proportions with vectors.

\section{Results and Discussion}

Hydrophysical properties. The conventional bark did not fit within the soilless substrate physical properties recommended standards in terms of AS $\left(0.35 \mathrm{~cm}^{3} \cdot \mathrm{cm}^{-3}\right)$ and CC $\left(0.41 \mathrm{~cm}^{3} \cdot \mathrm{cm}^{-3}\right.$; Bilderback et al., 2013). The guidelines of the nursery container substrates suggest that container capacity and air space of horticultural substrates should range from 0.45 to $0.65 \mathrm{~cm}^{3} \cdot \mathrm{cm}^{-3}$ and 0.10 to 0.30 $\mathrm{cm}^{3} \cdot \mathrm{cm}^{-3}$, respectively (Bilderback et al., 2013). Fractioning bark particles larger than $6.3 \mathrm{~mm}$ (including some proportions of bark fines due to aperture blockage) reduced CC $\left(0.29 \mathrm{~cm}^{3} \cdot \mathrm{cm}^{-3}\right)$ and increased AS $(0.39$ $\mathrm{cm}^{3} \cdot \mathrm{cm}^{-3}$; Table 1). Conversely, fractioning bark particles smaller than $6.3 \mathrm{~mm}$ or incorporating fibrous amendments had similar effects, where $\mathrm{CC}$ was increased and AS was decreased, when compared with conventional bark (Table 1). Fine particles often nest within pores of larger particles, which is shown to decrease AS and increase CC (Altland et al., 2018; Richards et al., 1986), while fibrous amendments can improve connectivity between particles (Jahromi et al., 2020) and increase surface area (Wallach, 2008).

It is suggested by many that soilless substrate TP should be maintained between 0.50 to $0.85 \mathrm{~cm}^{3} \cdot \mathrm{cm}^{-3}$ for optimal plant growth (Bilderback et al., 2013; Jackson et al., 2009a; Yeager et al., 2007). The absence of fine particles decreased coarse bark's TP $(0.67$ $\mathrm{cm}^{3} \cdot \mathrm{cm}^{-3}$ ) relative to conventional bark. The addition of fibrous materials increased TP in bark:peat and bark:coir $\left(0.82 \mathrm{~cm}^{3} \cdot \mathrm{cm}^{-3}\right.$ and $0.84 \mathrm{~cm}^{3} \cdot \mathrm{cm}^{-3}$, respectively, Table 1) compared with conventional bark. Fine bark had greater TP than coarse bark, which may attribute to more particles within the same volume, accrediting to the greater $\mathrm{D}_{\mathrm{b}}$ than coarse bark.
The greatest percentage of extra-large particles was in coarse bark $\left(0.31 \mathrm{~g} \cdot \mathrm{g}^{-1}\right)$ when compared with all other substrates, whereas fine bark had the least $\left(0.00 \mathrm{~g} \cdot \mathrm{g}^{-1}\right.$; Table 1$)$. Fine bark, bark:peat, and bark:coir contained $2 \times$ fine particles than that of coarse bark. The fine-sized particle proportions were different for all substrates $(P=0.0020)$. In each particle arrangement, all substrates were different (Table 1).

Bark form, geometry, and relative surface area are influential to substrate hydrophysical properties (Fields et al., 2014a). The hydraulic properties of the substrates can be modified by their relative particle size distribution. Fine particles increase surface area and thereby improve water-holding capabilities, whereas coarse particles increase pore diameter, which improves drainage (Brady and Weil, 1996). Engineering the geometries of the bark particles and incorporating conventional bark with fibrous amendments will influence pore space and water retention (Table 1). The addition of fibrous amendments increased $\mathrm{CC}, \mathrm{TP}$, and $\mathrm{D}_{\mathrm{b}}$, and decreased AS. Screening bark particles larger or smaller than $6.3 \mathrm{~mm}$ also has influence on $\mathrm{CC}, \mathrm{AS}, \mathrm{TP}$, and $\mathrm{D}_{\mathrm{b}}$.

Stratified substrate growth trial. Crop growth was affected 36 DAI by both substrate $(P=0.0350)$ and irrigation $(P=0.0101)$, where crops grown under SA and CA irrigation regimens outgrew those grown in the deficit irrigation treatments. The authors expect this early growth is due to plants overcoming transplant shock and quickly establishing developing root systems (Grossnickle, 2005; Fig. 2A and C) under more ideal water conditions. Plants grown in stratified treatments outgrew plants grown in CTL treatment bark under SA because the stratified system has potential to provide young plants more optimal initial growing conditions due to the incorporation of unique substrate amendments (Fields, 2016; Jahromi et al., 2020; Scagel, 2003) in the upper half of the container resulting in improved water retention (Table 1; Altland et al., 2018; Fields et al., 2014a) and air-filled porosity in the lower half of the container (Fields et al., 2021) to help establishment (Fig. 2A). Whereas in CTL substrates, due to gravitational forces quickly driving water movement downward, the upper portion of the substrate was drier than the lower half (Owen and Altland, 2008), resulting in inefficient moisture gradients and water flux quickly percolating through the profile (Hoskins et al., 2014c). Plant liners grown in conventional bark may have experienced water stress due to these drier conditions in the top half of the container (Kingston et al., 2017) and the undesirable water gradient resulted in wet conditions below plant liner roots, further restricting root growing space (Mathers and Leidenfrost, 1995; Mathers et al., 2007). Therefore, the top strata substrate components within the stratified system had an increased amount of available water (bark:coir, Jahromi et al., 2020; bark:peat, Fields et al., 2021) compared with conventional pine bark (Fields et al., 2014a) and subsequent ability to transfer water 
Table 1. Static physical properties and particle size distribution of conventional bark, coarse bark, fine bark, and 75\%:25\% bark:peat and bark:coir blend by volume.

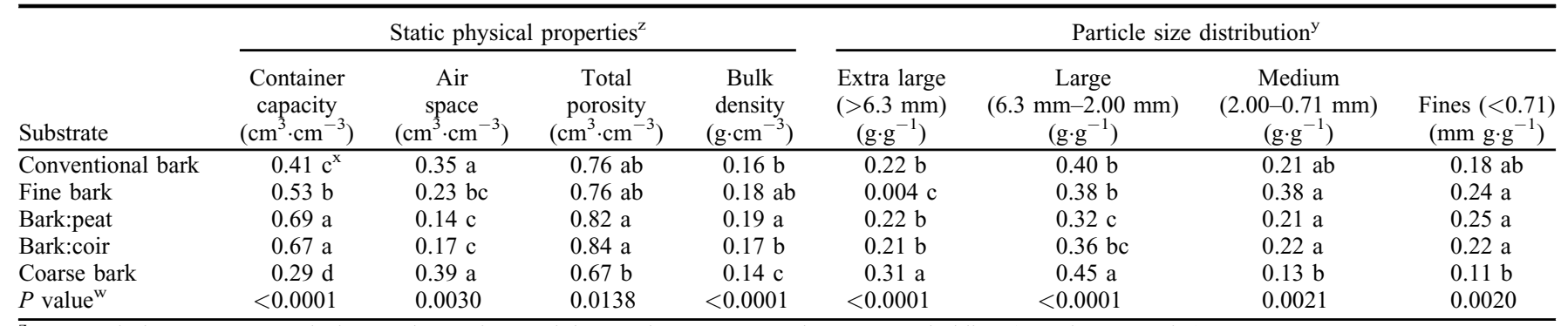

${ }^{\mathrm{z}}$ Measured via porometer analysis. Total porosity $=$ minimum air space + maximum water holding (container capacity).

${ }^{\mathrm{y}}$ Percent of particle dry weight occupying extra large $>6.3 \mathrm{~mm}$, large $>2.00 \mathrm{~mm}$, medium $>0.71 \mathrm{~mm}$, and fines $<0.71 \mathrm{~mm}$.

${ }^{\mathrm{x}}$ Letters denote detected differences among means of five substrates (conventional bark, fine bark, bark:peat, bark:coir, and coarse bark) using Tukey's honestly significant difference $(\alpha=0.05)$ within columns.

${ }^{\mathrm{w}}$ Measures of overall treatment effects using analysis of variance with a significance value of $(\alpha=0.05)$.

(unsaturated hydraulic conductivity; Fields, 2016) to sustain crop growth during dry/drying conditions. Wallach (2008) found that when placing a tensiometer in the upper and lower half of the container under "dry" and "wet" treatments, the wet (i.e., greater moisture contents) treatments did not experience as negative matric potentials in upper portion of the container. Thus, the increased water retention in all top strata possibly should allow increased access to plant available water.

Plants grown in CTL grew the best in SD when compared with other irrigation schedules. However, plants grown in CTL had the lowest survival rate across substrate treatments and irrigation treatments, especially in CD. Possibly, conventional bark is more efficient in single irrigations with larger quantities of water. To expand, the infiltrating water in CTL spread more or as evenly throughout the container in SD, similar to the stratified systems. However, in $\mathrm{CD}$, plants grown in

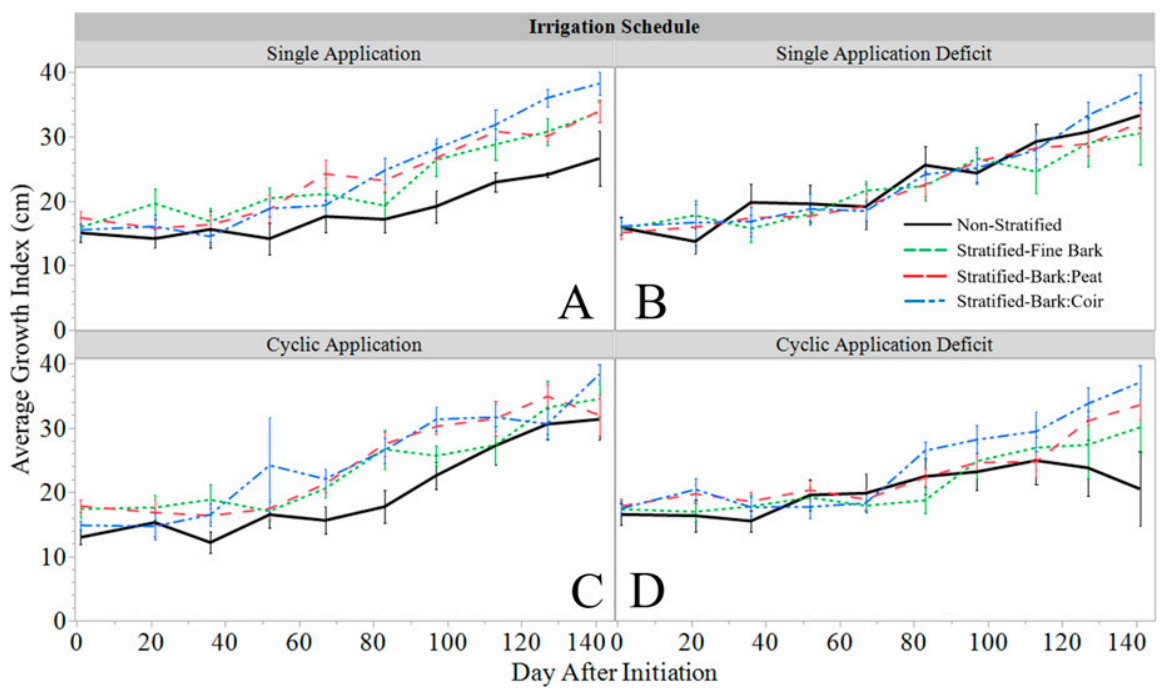

Fig. 2. Growth index of containerized plants grown in four experimental substrates and four irrigation schedules. Experimental substrates included a control of conventional pine bark (CTL), and three stratified systems. The stratified systems all contained coarse bark particles $(>6.3 \mathrm{~mm})$ complementary paired in the upper strata with either included fine bark $(<6.3 \mathrm{~mm})$, a $75 \%: 25 \%$ bark:peatmoss and bark:coconut coir blend by volume. Irrigation schedules include (A) single application (SA; $1 \times 1$ day), (B) single application deficit (SD; 75\% of SA), (C) cyclic application (CA; SA/3, 3×/day), and (D) cyclic application deficit ( $75 \%$ of CA).

CTL had poor growth and survival rates because there was little water available for plant utilization in the media. As a result, water was held at low tensions, which can decrease hydraulic conductivity; whereas in the upper strata in stratified treatments, water was retained in sufficient proportions and reduced the tendency of reaching low tensions, even in water-deficit conditions. Hillel (2004) discussed that hydraulic conductivity decreases with descending moisture status. Furthermore, Fields et al. (2017) showed that fine bark and bark-coir had greater unsaturated conductivity than conventional pine bark. Hence, with the increased water retention of the stratified treatments in concert with increased hydraulic conductivity, there was more water available in the upper strata.

The deep irrigations in SA and SD allowed the stratified system to have a more uniform water content throughout the substrate profile. The upper strata enabled the irrigation water

.
face evaporation, and plant uptake. This was also observed by Milks et al. (1989) where volumetric water content in the upper half of the container was at $32 \%$ and was increased to $69 \%$ in the lower half. Therefore, the stratified system was designed to enable water retention strategically throughout the container profile where water is often lost quickly to provide optimal environments for establishing plants. For example, during the establishment stages, young-plant roots have not yet explored the container. Hence, as plant roots establish themselves, roots are generally concentrated in the top half of the container, generating plant-water demand in the upper substrate strata, while water in the lower strata goes unused. This unused bottom portion of the substrate often creates waterlogged conditions and potentially reduces required air exchange to the lower rhizosphere. Growers must, therefore, replenish water in the upper portion of the substrate to maintain proper plant health through frequent watering (Fields et al., 2021). As a result of the stratified system, roots concentrated in the upper portion of the container may not have experienced as strong of tensions that CTL substrates may have, thereby 
stable enough to endure both root uptake and evaporative demand.

All plants grown in stratified treatments outgrew plants grown in CTL in CA and CD (Fig. 2C and D). One goal of stratifying substrates is to surpass the unfavorable gravitational water gradient that occurs in the container, while simultaneously allowing resources to be readily available for root utilization as young, transplanted plant roots explore the profile from the substrate surface downward. Bauters et al. (2000) found that in sands at high moisture content, the wetting front was slower and wider than at lower moisture contents. Therefore, a drier upper half in CTL substrates may have resulted in faster water flow and channeling and slowed as the wetting front approached the wetter bottom portion (Hoskins et al., 2014c). Hence, stratified substrates may enable a more uniform wetting front due to greater water contents where water first enters the profile at the substrate surface. In addition, stratified substrates may be able to support plant growth with more frequent, shallow (i.e., reduced irrigation load; quantities of water sufficient enough to replenish the water reservoir that is lost in the upper portion of the substrate) irrigations, through added retention of water in the upper strata. The shallow irrigations may enhance the stratified system to increase moisture retention in the upper half and subsequently prevent/reduce shallow rooting from occurring when growers overwater (Taylor et al., 2013), and waterlogging occurs at the container bottom (Mathers and Leidenfrost, 1995), leading to poor gas exchange. The ability to hold adequate water in the upper portion mediated the hysteretic influences until the next subsequent irrigation and facilitated/ reduced plant water stress during a critical and fragile period (i.e., transplant shock and lack of a developed root system), resulting in quicker growth. Mathers et al. (2007) stated that coarse particles increase the quantity of large diameter gravitational pores, which in turn increases the amount of air occupied within pore spaces after gravitational drainage occurs (at CC). Because of increased gravitational pores, there are more air-filled pores in CTL after gravitational drainage, and water is held at lower tensions within its capillary pores. As water is distributed throughout the substrate profile to maintain equilibrium, substrate particles hold onto water molecules more strongly. Hence, where young plant roots are more likely to be concentrated and where high evaporative demand is present (i.e., upper half of the container), there would be less water available to the plant and stronger hysteretic influences. It is likely that in CTL, where AS is higher in the upper strata compared with stratified systems, there were greater desorption (i.e., drying) influences than sorption (i.e., wetting/retention) after watering. This may allude to CTL being incapable of easing hysteretic forces and balancing drying/wetting curves.

As daylight and temperatures decreased (Fig. 1), the crops were irrigated every other day beginning 113 DAI while continuing their respective irrigation schedule. Subsequent measures of plant growth showed that there was a decrease of plant growth rate in CD when grown within CTL after 113 DAI (Fig. 2D). The interaction between substrate and irrigation $(P=0.0493)$ influenced plant growth index from 113 DAI until harvest. One of the favorable properties of conventional pine bark that gives the substrate popularity in the southern horticultural industry is its ability to effectively drain water well (Pokorny et al., 1986). Thus, it is hypothesized that when the CTL treatments received low quantities of water in CD (i.e., every other day), the plants were severely water stressed as the upper portion of the container dried due to root uptake and evaporative demand (Lobet et al., 2014). Nevertheless, the decrease in growth within $\mathrm{CD}$ was not observed among the stratified treatments. When $\mathrm{FB}, \mathrm{BP}$, and $\mathrm{BC}$ received low quantities of water in $\mathrm{CD}$, the crops continued to grow (Fig. 2D). This may suggest that the upper strata in the stratified system was capable of retaining sufficient water.

Fields et al. (2014b) showed that coir held more water than peatmoss at substrate water potential of $-300 \mathrm{hPa}$ and $-1.5 \mathrm{MPa}$. Moreover, Fields (2016) concluded that coir has a higher unsaturated hydraulic conductivity than peat under drier conditions. Therefore, even though $\mathrm{BP}$ and $\mathrm{BC}$ retained greater quantities of water in the upper strata (Table 1 ), additional water was available to plants in the $\mathrm{BC}$ under low water tensions or drying conditions (as observed in CD). This reduces the energy required by roots to absorb water from the drying substrate and decreases water stress indicators. Jahromi et al. (2020) showed that increasing percentages of coir to pine bark improved volumetric water content over the range of easily available water and water buffering capacity ( -1 to $-5 \mathrm{kPa}$ and -5 to $-10 \mathrm{kPa}$, respectively). Especially with when coir was incorporated to bark at rates of $25 \%, 40 \%$, and $65 \%$ by volume, these substrates had the greatest water content among all tensions. In addition, it has been demonstrated by Jahromi et al. (2020) that coir-amended bark allowed for greater available water at both high and low moisture contents. This suggests that $\mathrm{BC}$ did well in $\mathrm{CD}$ because the coir minimized water stresses under severe water reductions by increasing the availability of water remaining in the substrate.

Kirda and Kanber (1999) suggest that it is imperative to understand the physiological water stress of each crop before implementing a deficit irrigation regimen. Fereres and Soriano (2007) stated that irrigating crops below their relative maximum ET rate can negatively affect crop yields. Therefore, deficit irrigation may be productive only when the crop's ET potential is not compromised. Growers may, however, optimize irrigation efficiency through deficit irrigation strategies using the stratified system, where it is likely that lower quantities of water may have been sufficient in hydrating the container system for plant utilization.
Measured at final harvest, there was an interaction between substrate and irrigation schedules on plant growth index $(P=$ 0.0141 ). The plants grown in the conventional bark treatment had the lowest final growth index in each irrigation schedule, except in SD, where they grew as well as the other treatments (Fig. 2B). Crop survival rate was the greatest in SA and the least in $\mathrm{CD}$, whereas plants grown in $\mathrm{BC}$ had the greatest survival rates and plants grown in CTL experienced the lowest rate of survival (Table 2). Since the upper portion of a container often is dryer than the lower half due to gravitational forces (Fonteno, 1989; Milks et al., 1989), the low survival rates of plants grown in CTL can be attributed to reduced available water in the top portion.

There was no detectable substrate $(P=$ $0.8182)$ or irrigation $(P=0.6027)$ effect on $\mathrm{R}: \mathrm{S}$; however, substrate strongly influenced shoot $(P=0.0060)$ and $\operatorname{root}(P=0.0342)$ dry weight independently. Coconut coir allows increased access to water, as substrate water tension decreases when compared with peat and bark (Asiah et al., 2004; Fields et al., 2017). Coir can hold up to nine times its weight in water due to its finer particles (Mason, 2004). Thus, it is hypothesized that the increased water retention in bark:coir is responsible for the increase in mass per unit plant height (Bayer et al., 2013). In addition, plants grown in the BC treatment had the greatest final growth index within each irrigation schedule (Fig. 2A-D). Jahromi et al. (2020) showed that plants grown in coiramended bark had an increase in photosynthetic rates. This increase can be reflected in other growth parameters, such as plant dry weights and growth index. A consequence of increased photosynthetic rates requires greater plant water demand to facilitate cell enlargement, which can explain an increase in crop growth (Fig. 2). As demonstrated in Fig. 3, plants grown in $\mathrm{BC}$ appear to have the fullest form in SA and CD among other substrate treatments. Furthermore, Cai et al. (2012) indicated plants that did not experience water stresses resulted in promoted root growth and exploration. Therefore, because plants grown in $\mathrm{BC}$ were less affected by abiotic stresses, this was further confirmation of the increased growth among the substrate treatment (Fig. 2A-D).

Substrate influenced $\Delta$ GI (difference in final growth index - initial growth index) $(P=0.0040)$, where plants grown in BC substrates had the greatest difference among the other substrate treatments in each irrigation schedule (Table 2). These results were similar to Fields (2016), where $\Delta$ GI was greater in plants grown in bark amended with coconut coir, when compared with plants grown in fine bark $(<4.0 \mathrm{~mm})$ and bark amended with peatmoss. There was a strong interaction between substrate and irrigation $(P=0.0082)$ on root index. In CD, the root growth in CTL treatments was probably inhibited $(14.7 \mathrm{~cm}$; Table 2) due to water stresses (Cai et al., 2012), whereas the roots in BC treatments were likely promoted $(20.4 \mathrm{~cm}$; Table 2$)$ due 
Table 2. Plant physiological and morphological measures. Experimental substrates include a control of conventional pine bark (CTL), and three stratified systems. The stratified systems all contained coarse bark particles $(>6.3 \mathrm{~mm})$ complementary paired in the upper strata with included fine bark $(<6.3$ $\mathrm{mm}$ ), a 75\%:25\% bark:peat, and bark:coir blend by volume. Irrigation schedules include a single application (SA; $1 \times /$ day), single application deficit (SD; $75 \%$ of SA), cyclic application (CA; SA/3, 3×/day), and a cyclic application deficit (CD; $75 \%$ of $\mathrm{CA}$ ).

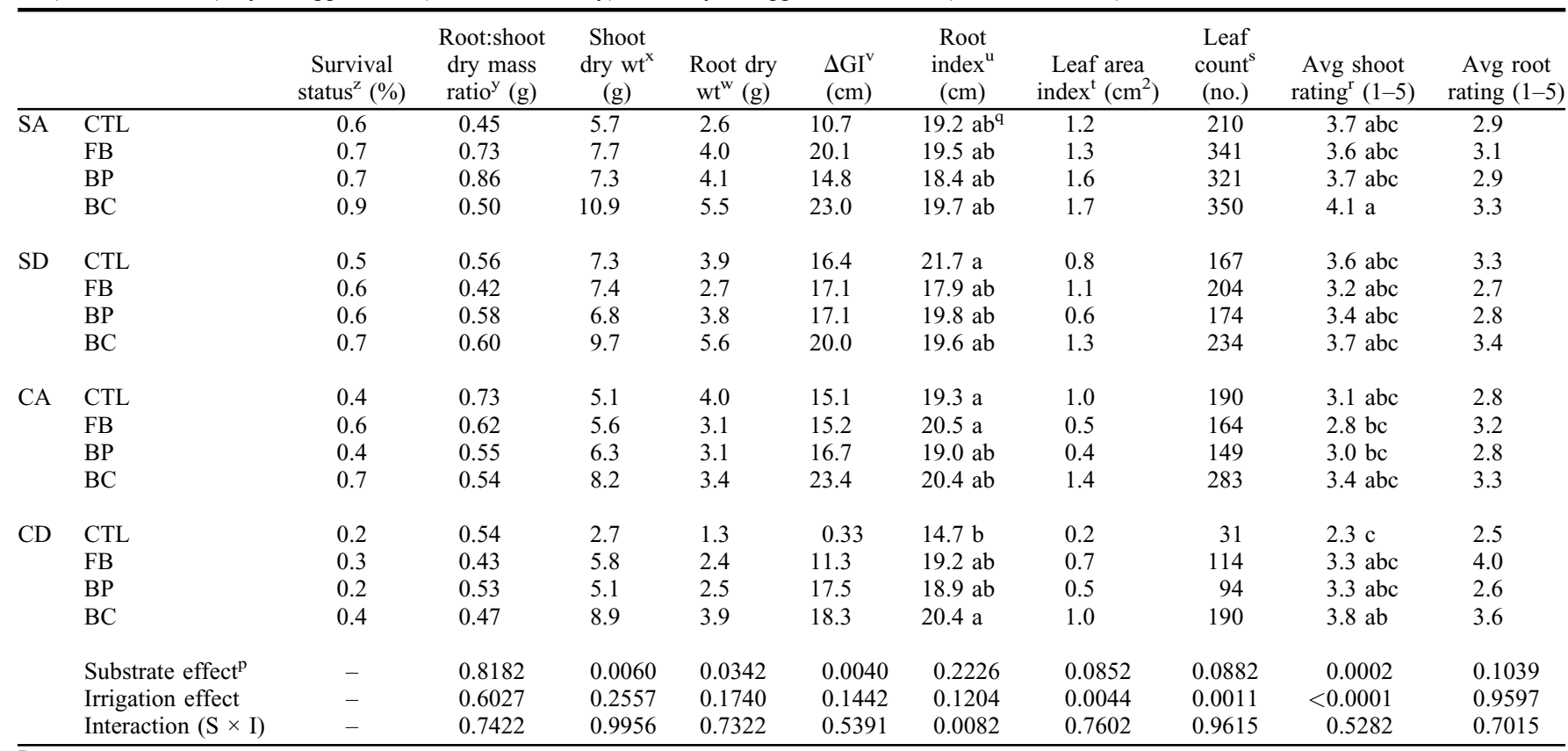

\footnotetext{
${ }^{\mathrm{z}}$ Number of alive plants within a substrate treatment divided by 14 (total number of plants per irrigation schedule at initiation of study).

${ }^{\mathrm{y}}$ Dry mass of root system $\div$ dry mass of shoot system.

${ }^{\mathrm{x}}$ Shoot dry mass dried at $23.7^{\circ} \mathrm{C}$ for $6 \mathrm{~d}$.

${ }^{\mathrm{w}}$ Root dry mass dried at $23.7^{\circ} \mathrm{C}$ for $6 \mathrm{~d}$.

${ }^{\mathrm{v}}$ Difference in final growth index - initial growth index.

${ }^{\mathrm{u}}($ Deepest rooting depth + width of root system + perpendicular width $) / 3$.

${ }^{t}$ Leaf surface area $\div$ surface area of substrate surface.

${ }^{\mathrm{s}}$ Leaves counted by hand and the average was calculated.

${ }^{\mathrm{r}}$ Rating is a subjective measure from three individuals and the average was calculated.

${ }^{\mathrm{q}}$ Letters denote detected differences among means of a full factorial including 4 substrates (CTL, FB, BP, and BC) and four irrigations (SA, SD, CA, and CD) using Tukey's honestly significant difference test $(\alpha=0.05)$ within columns.

${ }^{\mathrm{p}}$ Measures of overall treatment effects using analysis of variance using a significance level $(\alpha=0.05)$.

$\mathrm{FB}=$ stratified-fine bark; $\mathrm{BP}=$ stratified-bark:peat; $\mathrm{BC}=$ stratified-bark:coir.
}

to increased hydraulic conductivity yielding more water availability in coir (Fields et al., 2017). Root growth in CTL under SD was similar to root growth in $\mathrm{BC}$ treatments under $\mathrm{CD}$ (Table 2). This is possibly because roots grown in CTL were stressed enough to promote root growth in SD, but significantly enough to reduce root growth as observed in CD (Table 2). As illustrated in Fig. 3, unlike the stratified treatments that do not appear to have severe water deficit impacts, plants grown in CTL under $\mathrm{CD}$ irrigation had poor-quality growth with a diminutive shoot canopy.

There was a strong irrigation effect on LAI and leaf count $(P=0.0044$ and $P=0.0011$, respectively); however, there were no detectable differences of LAI and leaf count among the substrate treatments across irrigation schedules (Table 2). Water stresses have been shown to increase leaf abscission (Gu et al., 2007) and decrease leaf area (Graves et al., 2002) due to the inhibition of cell division and elongation, leaf curl, and death (Blum, 1996). The authors predicted in SA, there would be more water available for leaf growth, which would result in increased leaf count and area; however, these results were not observed
(Table 2). It did appear that plants grown in FB and BC had the most inclusive growth under SA (Fig. 3). There was a strong substrate $(P=0.0002)$ and irrigation $(P<$ 0.0001 ) effect on subjective shoot quality ratings. The plants grown in BC treatments received the greatest quality ratings and were statistically different in $\mathrm{CD}$ among the substrate treatments, whereas plants in CTL received poorer quality ratings than plants grown in $\mathrm{BC}$ in $\mathrm{CD}$ (Table 2; Fig. 2). There were no detectable effects on subjective root quality ratings from substrate $(P=0.1039)$ or irrigation $(P=0.9597)$. Substrate stratification, especially when grown in $\mathrm{BC}$, enhanced crop growth and quality (Figs. 2 and 3), facilitated transplant shock for young plants, especially during hot environmental conditions, and was capable of maintaining plant growth when water inputs were reduced.

Nutrition analysis. Substrate fertility was analyzed via a pour-through analysis (Fig. 4). The authors hypothesized that stratified substrates would retain more nutrients in the upper strata, available for nearby root utilization, and therefore, would increase nutrient foliar percentages and decrease nutrient concentrations within container leachate. However, it was not observed that stratified substrates discernably reduced nutrient-enriched leachate concentrations relative to conventional bark.

Substrate and irrigation schedule had a strong effect on pour-through pH $(P=0.0127$ and $P=0.0192$, respectively). Pine bark is inherently low in $\mathrm{pH}$ due to several factors such as organic acids, like acetic, formic, and oxalic acids, and polyphenols within bark, the harvesting process (i.e., anerobic and microbial decomposition), season of harvest, and types of tree species (Jackson, 2020). Liming the bark was therefore required. There is an increase in $\mathrm{pH}$ across all substrate treatments from 9 DAI to 41 DAI due to lime activation raising substrate $\mathrm{pH}$ levels (Altland and Jeong, 2016; Fig. 4A-D). Most stratified substrates had a lower $\mathrm{pH}$ values than CTL in $\mathrm{SA}, \mathrm{SD}$, and $\mathrm{CA}$, with the exception of $\mathrm{BC}$, which had the greatest $\mathrm{pH}$ in $\mathrm{CD}$, when compared with other substrate treatments (Fig. $4 \mathrm{~A}-\mathrm{D})$. This is likely due to greater $\mathrm{pH}$ of the coir component when compared with peat (Evans et al., 1996). However, it was predicted to see higher $\mathrm{pH}$ levels in CTL 


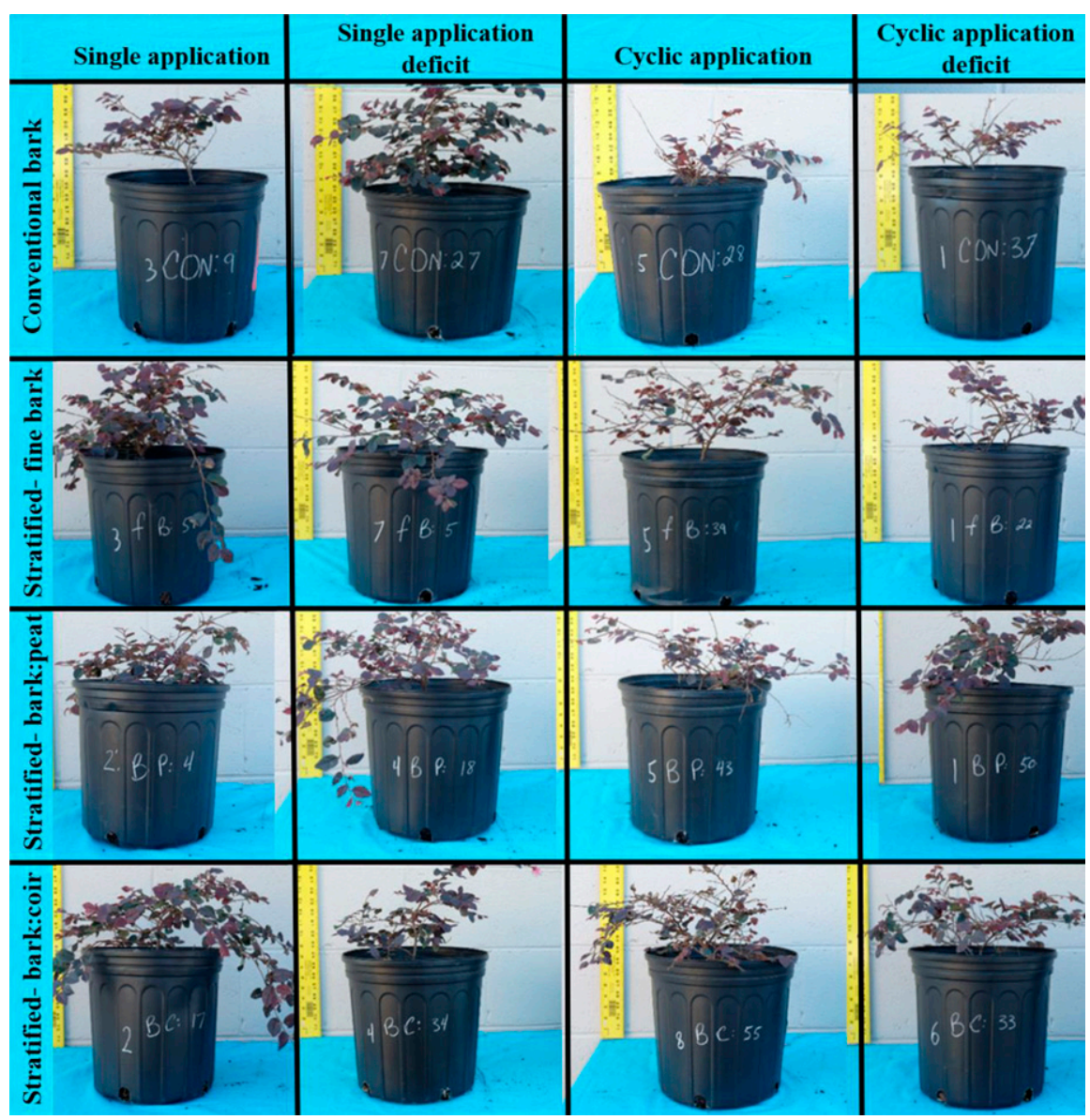

Fig. 3. Representative replicates of Loropetalum chinensis 'Ruby' shoots grown in four experimental substrates and four irrigation schedules. The $\mathrm{x}$-axis lists irrigation schedules, and the $\mathrm{y}$-axis lists the corresponding substrate treatments.

treatments than the stratified treatments. Because there is more surface area in bark fines, peatmoss, and coconut coir relative to conventional bark, more lime would therefore be required to cover the increased exchange sites (Raviv and Lieth, 2008). This can be especially seen in FB, where the treatment had a lower $\mathrm{pH}$ in $\mathrm{SA}$ and $\mathrm{CA}$ when compared with other substrate treatments and had a lower $\mathrm{pH}$ than CTL pour-throughs in all irrigation schedules (Fig. 4A-D). Pancerz and Altland (2020) showed the $\mathrm{pH}$ buffering capacity of pine barks increased as particle size decreased. In addition, Altland et al. (2014) showed that cation exchange capacity (CEC) increases as particle size decreases. As CEC increases, the $\mathrm{pH}$ buffering capacity of substrates is also influenced (Altland et al., 2014). Therefore, greater proportions of extra-large particles (Table 1) in CTL may have decreased its $\mathrm{pH}$ buffering capacity resulting in higher $\mathrm{pH}$ levels.

There was no detectable substrate $(P=$ $0.8458)$ or irrigation $(P=0.0560)$ effect on pour-through EC measurements (Fig. 4E-H) over the course of the study. In addition, bark amended with peat or coir has been shown to reduce EC pour-through levels compared with traditional bark due to the increased CEC of peat and coir (Kingston et al., 2017). The increased water retention in the upper strata of the stratified substrates likely reduced preferential flow. Furthermore, Fields et al. (2014a) showed that bark has only $\approx 20 \%$ of the easily available water that exists in peat and coir. Increased CEC sites from finer bark particles and peat/coir additions in the upper strata, in concert with more accessible water (Table 1), suggest that stratified substrates can reduce leaching of excess nutrients and allow for more available nutrient root uptake and utilization.

Nitrogen, phosphorus, and potassium $(\mathrm{N}$, $\mathrm{P}, \mathrm{K}$, respectively) are the three nutrients required in the highest concentrations for plant growth and development (Mason, 2004). It was hypothesized that there would be a reduction in foliar macronutrients present in plant leaves when grown in CTL substrates (i.e., $\mathrm{N}$ and $\mathrm{P}$ in the form of nitrate and phosphate, respectively, due to mobility in substrates) under SA irrigation because greater quantities of water can readily leach nutrients that are not strongly held by substrate particles (Nzokou and Cregg, 2010). It was also hypothesized that plants grown in CTL would have lower analysis because of reduced growth and would thus have lower requirements for nutrient uptake (Nzokou and Cregg, 2010). However, no statistical differences in $\mathrm{N}$ and $\mathrm{P}$ foliar percentages were observed amongst substrate treatments (Table 3). Intriguingly, peat and percentages of macronutrients in their foliar coir have been known to improve root nutrient uptake when compared with traditional bark (Kingston et al., 2017); however, the foliar analysis showed no differences among substrate and irrigation treatments in foliar $\mathrm{N} \%$ and $\mathrm{P} \%$ (Table 3). Lower crop growth as observed in plants grown in CTL (Fig. 2A and D) can account for a reduced demand of nutrient requirements (Nzokou and Cregg, 2010), but there were no observed differences in foliar macro- and micronutrients of plants grown in CTL (Table 3). Substrate stratification may improve nutrient efficiency and utilization in the upper portion of the container due to the high CEC of fine bark (Altland et al., 2014), peat, and coir relative to traditional bark (Raviv and Lieth, 2008). Thus, it is warranted that more research focused solely on mineral nutrition within stratified substrates composed of different components is needed. Substrate $(P=0.0902)$ and irrigation $(P=$ 0.1308 ) had no effect on $\mathrm{P} \%$ (Table 3 ); however, these results contrast with Kingston et al. (2017), where increasing percentages of peat improved $\mathrm{P}$ and $\mathrm{K}$ uptake compared with coir.

Irrigation had a strong effect on foliar $\mathrm{K} \%$ ( $P=0.0004$; Table 3$)$. Coconut coir has been documented to contain high percentages of $\mathrm{K}$ (Evans et al., 1996), which may result in an increase in $\mathrm{K}$ uptake due to nutrient abundance, although no discernable differences were observed in foliar $\mathrm{K} \%$ in $\mathrm{BC}$ (Table 3). Irrigation had a strong effect on calcium $(\mathrm{Ca})$ concentration $(P=0.0004$; Table 3$)$. Nzokou and Cregg (2010) showed that there is greater $\mathrm{Ca}$ uptake in crops as more water is available to plant roots. Calcium is very influential for plant tolerance of abiotic stressors such as drought, regulation of stomatal closures, and facilitation of other physiological functions (Gómez-Pérez et al., 2014). Deficiencies in calcium in woody plants have been shown to lead to a reduction in cambial activity and vessel size (Fromm, 2010). Uniquely, plants grown in BC treatments had the lowest percentages of foliar $\mathrm{Ca}$ in $\mathrm{CA}(0.91 \%)$ and plant leaves in FB had the greatest in SA $(1.29 \%$; Table 3). However, there were no observations in a reduction of growth in CA among plants grown in $\mathrm{BC}$ treatments (Fig. 2C). There was no substrate $(P=0.2462)$ or irrigation $(P=$ $0.2522)$ effect on foliar magnesium $(\mathrm{Mg}$; Table 3). Iron (Fe) was used as a representative foliar micronutrient. There were no significant differences among substrate and irrigation treatments in foliar Fe concentrations.

Hoskins et al. (2014b) state that dry substrate in the upper portion of the container can lead to preferential flow and channeling, creating a nonuniform hydraulic gradient. Preferential flow and channeling may lead to a quick escape of nutrients. Thus, nutrient deficiencies may occur, and environmental contamination becomes prevalent (Taylor et al., 2013). It was hypothesized that in CTL treatments, there would be more concentrated nutrient-enriched leachate because of larger pores in the upper strata than in the stratified system, resulting in channeling, but few differences were observed. There was a strong substrate $(P=0.0140)$ effect on nitrate 


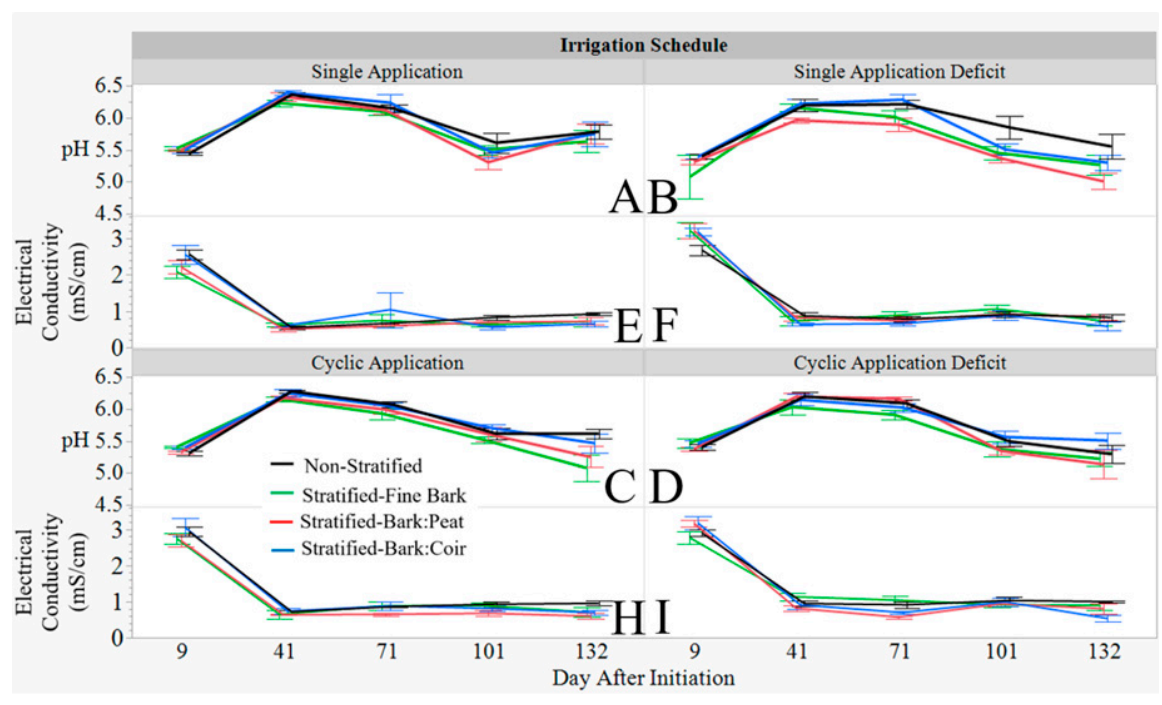

Fig. 4. Pore-water fertility [pH and electrical conductivity (EC)] assessed on Loropetalum chinensis 'Ruby' across four substrate and four irrigation treatments. $\mathrm{pH}$ measurements within (A) single application (SA; 1×/day), (B) single application deficit (SD; 75\% of SA, $1 \times /$ day), (C) cyclic application (CA; SA/3, 3×/day), and (D) cyclic application deficit (CD; 75\% of CA, $3 \times /$ day), across substrate treatments. EC measurements within (E) single application (SA; 1 $\times /$ day), (F) single application deficit (SD; 75\% of SA, $1 \times /$ day), (H) cyclic application (CA; SA/3, 3×/day), and (I) cyclic application deficit $(\mathrm{CD} ; 75 \%$ of $\mathrm{CA}, 3 \times /$ day), across substrate treatments.

leachate concentrations in the initial collection (Table 4). In the second leachate collection, CTL treatments had a significantly greater nitrate concentration than the first collection $(\approx 3 \times)$. This is likely indicative of controlled-release fertilizer releasing greater proportions of nutrients over time (Avent, 2003). Fare et al. (1994) demonstrated that orthophosphates by $2 \times$. The substrate treatment BP had the greatest phosphate concentration leachate under CA in July and, conversely, the least phosphate-concentrated leachate in October, parallel to the results of Zinati (2006) (Table 4). Substrate had a strong effect $(P=$ 0.0137 ) on ammonium concentrations in the first collection, where there were no discernable differences at the end of the study (Table 4). Phosphate was significantly affected by substrate $(P<0.0001)$ and irrigation $(P<$ $0.0001)$ at the beginning of the study; whereas at the end, there were no differences or effects (Table 4).

Substrate and irrigation affected potassium leachate concentration $(P=0.0046$ and $P<0.0001$, respectively; Table 4$)$ in the initial collection. It was predicted that $\mathrm{BC}$ treatments would release greater quantities of potassium, as it has been by shown by Evans et al. (1996) that coconut coir often contains high percentages of $\mathrm{K}$. Bark:coir had the highest percentages of $\mathrm{K}$ (Table 4) at the beginning of the study. This is likely because recurrent irrigations continuously leached $\mathrm{K}$ from the coir materials over the course of the study. Substrate had an effect on Ca leachate concentrations from the first and second collection dates $(P=0.0498$ and $P=0.0020$, respectively; Table 4). The substrate used in this study influenced the magnesium leachate concentrations within the first and second collections $(P=0.0310$ and $P=0.0451$, respectively).

Microbial communities. Proportions of long-term microbial communities are illustrated in Fig. 5. Microbial activities are

Table 3. Foliar nutrition. Leaves were harvested after plants were dried at $22.7^{\circ} \mathrm{C}$ for $7 \mathrm{~d}$. Plants grown in one of four substrate treatments: 1) conventional bark filled uniformly throughout the container 2) fine bark particles layered over coarse bark particles 3) unscreened bark:peat blend layered over coarse bark and a 4) bark:coir blend layered over coarse bark. These plants were grown under one of four irrigation schedules: 1) single application (SA), 2) single application deficit (SD), 3) cyclic application (CA), and a 4) cyclic application deficit (CD).

\begin{tabular}{|c|c|c|c|c|c|c|c|c|}
\hline Irrigation schedule & Substrate & $N(\%)^{z}$ & $\mathrm{P}(\%)$ & K (\%) & S (\%) & $\mathrm{Ca}(\%)$ & $\operatorname{Mg}(\%)$ & $\mathrm{Fe}(\mathrm{ppm})^{\mathrm{y}}$ \\
\hline \multirow[t]{2}{*}{$\overline{\mathrm{SA}}$} & $\overline{C T L}$ & 3.41 & 0.35 & $1.37 \mathrm{ab}^{\mathrm{x}}$ & $0.40 \mathrm{ab}$ & $1.12 \mathrm{ab}$ & 0.10 & 84.16 \\
\hline & $\mathrm{BP}$ & 3.93 & 0.49 & $1.63 \mathrm{ab}$ & $0.49 \mathrm{ab}$ & $1.18 \mathrm{ab}$ & 0.11 & 83.92 \\
\hline \multirow[t]{3}{*}{ SD } & $\mathrm{CTL}$ & 3.51 & 0.42 & $1.61 \mathrm{ab}$ & $0.50 \mathrm{ab}$ & $1.18 \mathrm{ab}$ & 0.09 & 86.52 \\
\hline & FB & 3.49 & 0.45 & $1.69 \mathrm{ab}$ & $0.43 \mathrm{ab}$ & $1.20 \mathrm{ab}$ & 0.11 & 77.96 \\
\hline & BP & 3.93 & 0.49 & $1.89 \mathrm{a}$ & $0.47 \mathrm{ab}$ & $1.15 \mathrm{ab}$ & 0.11 & 88.97 \\
\hline \multirow[t]{5}{*}{$\mathrm{CA}$} & CTL & 3.31 & 0.33 & $1.38 \mathrm{ab}$ & $0.42 \mathrm{ab}$ & $1.05 \mathrm{ab}$ & 0.09 & 82.51 \\
\hline & FB & 3.65 & 0.45 & $1.42 \mathrm{ab}$ & $0.45 \mathrm{ab}$ & $1.00 \mathrm{ab}$ & 0.10 & 127.12 \\
\hline & $\mathrm{BP}$ & 3.83 & 0.41 & $1.41 \mathrm{ab}$ & $0.50 \mathrm{ab}$ & $1.00 \mathrm{ab}$ & 0.10 & 100.04 \\
\hline & $\mathrm{BC}$ & 3.46 & 0.36 & $1.23 \mathrm{~b}$ & $0.39 \mathrm{~b}$ & $0.91 \mathrm{~b}$ & 0.10 & 88.88 \\
\hline & CTL & 3.25 & 0.39 & $1.72 \mathrm{ab}$ & $0.44 \mathrm{ab}$ & $1.00 \mathrm{ab}$ & 0.11 & 89.35 \\
\hline \multirow[t]{3}{*}{ CD } & FB & 3.51 & 0.36 & $1.62 \mathrm{ab}$ & $0.42 \mathrm{ab}$ & $1.02 \mathrm{ab}$ & 0.11 & 113.80 \\
\hline & Irrigation effect & 0.2195 & 0.1308 & 0.0004 & 0.2072 & 0.0004 & 0.2522 & 0.0656 \\
\hline & Interaction effect $(\mathrm{S} \times \mathrm{I})$ & 0.6377 & 0.6107 & 0.3047 & 0.0118 & 0.5389 & 0.5384 & 0.6506 \\
\hline
\end{tabular}

${ }^{\mathrm{z}}$ Foliar macronutrient concentration measured as a percentage.

${ }^{\mathrm{y}}$ Foliar micronutrient concentration measured in parts per million (PPM).

${ }^{\mathrm{x}}$ Letters denote detected differences among means of a full factorial including four substrates (CTL, FB, BP, and BC) and four irrigations (SA, SD, CA, and $\mathrm{CD})$ using Tukey's honestly significant difference test $(\alpha=0.05)$ within columns. Values with no letters denote no significant difference.

${ }^{\mathrm{w}}$ Measures of overall treatment effects using analysis of variance using a significance level $(\alpha=0.05)$.

$\mathrm{CTL}=$ conventional bark; $\mathrm{FB}=$ stratified-fine bark; $\mathrm{BP}=$ stratified-bark:peat; $\mathrm{BC}=$ stratified-bark:coir. 
Table 4. Leachate sample analysis. Containers were heavily irrigated and the leachate after $1 \mathrm{~h}$ was collected and analyzed for nutrient concentration. Plants grown in one of four substrate treatments: 1) conventional bark filled uniformly throughout the container 2) fine bark particles layered over coarse bark particles 3) unscreened bark:peat blend layered over coarse bark and a 4) bark:coir blend layered over coarse bark. Samples were collected in one of two irrigation schedules 1) single application (SA) and 2) cyclic application (CA).

\begin{tabular}{|c|c|c|c|c|c|c|c|c|}
\hline & & $\begin{array}{c}\text { Nitrate } \\
(\mathrm{ppm}) 6 \times \text { Total }^{\mathrm{z}}\end{array}$ & $\begin{array}{l}\text { Ammonium } \\
(\mathrm{ppm})\end{array}$ & $\begin{array}{c}\text { Phosphate } \\
\text { (ppm) }\end{array}$ & $\begin{array}{c}\text { Potassium } \\
(\mathrm{ppm})\end{array}$ & $\begin{array}{l}\text { Sulfate } \\
\text { (ppm) }\end{array}$ & $\begin{array}{c}\text { Calcium } \\
(\mathrm{ppm})\end{array}$ & $\begin{array}{c}\text { Magnesium } \\
(\mathrm{ppm})\end{array}$ \\
\hline & \multicolumn{8}{|c|}{ July $^{\mathrm{y}}$} \\
\hline \multirow[t]{4}{*}{ SA } & CTL & $127.97 b^{x}$ & 7.25 & $21.43 \mathrm{c}$ & 33.51 & $39.70 \mathrm{ab}$ & $32.53 \mathrm{bc}$ & $5.60 \mathrm{ab}$ \\
\hline & FB & $203.19 \mathrm{ab}$ & 14.04 & $28.16 \mathrm{bc}$ & 41.94 & $51.76 \mathrm{ab}$ & $39.63 \mathrm{abc}$ & $8.00 \mathrm{ab}$ \\
\hline & $\mathrm{BP}$ & $172.32 \mathrm{ab}$ & 13.87 & $29.62 \mathrm{bc}$ & 41.18 & $46.47 \mathrm{ab}$ & $37.55 \mathrm{ab}$ & $7.17 \mathrm{ab}$ \\
\hline & $\mathrm{BC}$ & $161.72 \mathrm{ab}$ & 7.70 & $26.53 \mathrm{bc}$ & 51.71 & $40.03 \mathrm{ab}$ & $28.27 \mathrm{c}$ & $5.78 \mathrm{ab}$ \\
\hline \multirow[t]{4}{*}{ CA } & CTL & $146.46 \mathrm{~b}$ & 10.75 & $31.74 \mathrm{bc}$ & 48.76 & $41.79 \mathrm{ab}$ & $39.28 \mathrm{abc}$ & $6.91 \mathrm{ab}$ \\
\hline & FB & $260.98 \mathrm{ab}$ & 19.41 & $41.38 \mathrm{ab}$ & 61.17 & $63.26 \mathrm{ab}$ & $48.76 \mathrm{abc}$ & $9.20 \mathrm{a}$ \\
\hline & $\mathrm{BP}$ & $241.55 \mathrm{ab}$ & 32.15 & $63.55 \mathrm{a}$ & 60.51 & $52.75 \mathrm{ab}$ & $43.08 \mathrm{abc}$ & $8.52 \mathrm{ab}$ \\
\hline & $\mathrm{BC}$ & $157.00 \mathrm{ab}$ & 5.30 & $33.00 \mathrm{bc}$ & 72.11 & $34.14 \mathrm{~b}$ & $31.95 \mathrm{bc}$ & $6.76 \mathrm{ab}$ \\
\hline Substrate effect $(\mathrm{S})^{\mathrm{W}}$ & - & 0.0140 & 0.0137 & $<0.0001$ & 0.0046 & 0.0014 & 0.0498 & 0.0310 \\
\hline Irrigation effect (I) & - & 0.1393 & 0.0830 & $<0.0001$ & $<0.0001$ & 0.1245 & 0.1071 & 0.0905 \\
\hline \multirow[t]{2}{*}{ Interaction $(\mathrm{S} \times \mathrm{I})$} & - & 0.6625 & 0.2923 & 0.0035 & 0.9626 & 0.2324 & 0.9566 & 0.9976 \\
\hline & \multicolumn{8}{|c|}{ October } \\
\hline \multirow[t]{4}{*}{ SA } & CTL & $330.33 \mathrm{a}$ & 12.36 & $28.21 \mathrm{bc}$ & 57.82 & $66.45 \mathrm{a}$ & $59.18 \mathrm{ab}$ & $7.13 \mathrm{ab}$ \\
\hline & FB & $216.35 \mathrm{ab}$ & 20.66 & $23.70 \mathrm{c}$ & 47.45 & $52.46 \mathrm{a}$ & $29.30 \mathrm{bc}$ & $6.05 \mathrm{ab}$ \\
\hline & $\mathrm{BP}$ & $247.21 \mathrm{ab}$ & 23.19 & $30.79 \mathrm{bc}$ & 58.34 & $61.62 \mathrm{a}$ & $43.76 \mathrm{abc}$ & $5.67 \mathrm{ab}$ \\
\hline & $\mathrm{BC}$ & $183.61 \mathrm{ab}$ & 12.48 & $23.41 \mathrm{c}$ & 46.80 & $48.32 \mathrm{a}$ & $28.58 \mathrm{bc}$ & $4.49 \mathrm{ab}$ \\
\hline \multirow[t]{4}{*}{$\mathrm{CA}$} & CTL & $296.98 \mathrm{ab}$ & 19.25 & $35.02 \mathrm{bc}$ & 72.23 & $74.39 \mathrm{a}$ & $71.04 \mathrm{a}$ & $9.37 \mathrm{a}$ \\
\hline & $\mathrm{FB}$ & $249.24 \mathrm{ab}$ & 22.29 & $30.76 \mathrm{bc}$ & 57.11 & $63.97 \mathrm{ab}$ & $44.56 \mathrm{abc}$ & $3.16 \mathrm{~b}$ \\
\hline & $\mathrm{BP}$ & $225.17 \mathrm{ab}$ & 14.58 & $22.09 \mathrm{c}$ & 48.08 & $44.53 \mathrm{ab}$ & $41.85 \mathrm{abc}$ & $4.51 \mathrm{ab}$ \\
\hline & $\mathrm{BC}$ & $236.38 \mathrm{ab}$ & 14.70 & $30.13 \mathrm{bc}$ & 62.63 & $57.71 \mathrm{ab}$ & $45.95 \mathrm{abc}$ & $7.74 \mathrm{ab}$ \\
\hline Substrate effect (S) & - & 0.0692 & 0.1667 & 0.5157 & 0.4784 & 0.1245 & 0.0020 & 0.0451 \\
\hline Irrigation effect (I) & - & 0.4029 & 0.8387 & 0.2924 & 0.2598 & 0.6164 & 0.0615 & 0.0658 \\
\hline Interaction $(\mathrm{S} \times \mathrm{I})$ & - & 0.8169 & 0.2212 & 0.1444 & 0.4723 & 0.2867 & 0.6165 & 0.3804 \\
\hline
\end{tabular}

${ }_{\mathrm{z}}$ Leachate nutrient concentration measured in parts per million (PPM).

${ }^{\mathrm{y}}$ Month of collection.

${ }^{\mathrm{x}}$ Letters denote detected differences among means of a full factorial including from four substrates (CTL, FB, BP, and BC) and four irrigations (SA, SD, $\mathrm{CA}$, and $\mathrm{CD})$ using Tukey's honestly significant difference test $(\alpha=0.05)$ within columns during two difference months. Values with no letters denote no significant difference.

${ }^{\mathrm{w}}$ Measures of overall treatment effects per collected month using analysis of variance using a significance level $(\alpha=0.05)$.

$\mathrm{CTL}=$ conventional bark; $\mathrm{FB}=$ stratified-fine bark; $\mathrm{BP}=$ stratified-bark:peat; $\mathrm{BC}=$ stratified-bark:coir.

imperative for pine bark composting processes (Davis et al., 1992). Microbial activity aids in the degradation and break down of readily available carbon stored within pine bark. Composted (or aged) pine bark has been observed to have little $\mathrm{N}$ immobilization and slower decomposition rates, whereas uncomposted (or fresh) bark can show high $\mathrm{N}$ immobilization due to a high $\mathrm{C}: \mathrm{N}$ ratio and quicker decomposition rates (Raviv and Lieth, 2008). This degradation has been shown to stabilize the physical and chemical properties of pine bark to be effectively used as the primary soilless substrate in southern nurseries (Buamscha et al., 2008). Considering many soilless substrates are very high in organic material, hold sufficient quantities of water, and experience high heat within the container (Harris, 1967) during the growing season, it creates a suitable environment for microbial activity (Whitcomb, 1984). It is generally viewed that the cutoff point of immobilization/mobilization of organic matter is a $\mathrm{C}: \mathrm{N}$ ratio of $25-30: 1$. Because of the relatively high $\mathrm{C}: \mathrm{N}$ ratio of pine bark, much of the ammonium and nitrate can be immobilized during decomposition. Because there is a large quantity of degradable carbon, microbes will decompose the pine bark quickly and will need supplemental nutrients, most often N (Jackson et al., 2009b).

The authors therefore hypothesized there would be an abundance of microbial comm- unities across substrate treatments because of high proportions of bark and organic amendments. The interaction between substrate and irrigation $(P=0.0080$; Fig. $5 \mathrm{~A}-\mathrm{C})$ and between substrate vs. strata layer $(P=0.0010$; Fig. 5D-F) had an effect on microbial proportions. It was hypothesized there would be strong differences in BP samples because sphagnum mosses are relied on by microbial activities to assist in the degradation of peat bogs (Tian et al., 2019). The result herein showed that the upper strata in BP under cyclic irrigation had the greatest percentages of actinomycetes, whereas the top strata of FB under single application contained the fewest (Table 5; Fig. 5B).

There were greater proportions of actinomycetes in BP under cyclic application (Fig. $5 \mathrm{~F})$ where $\mathrm{BP}$ had the greatest variation among other treatments. Possibly, increased quantities of water in concert with peatmoss specifically allowed for suitable habitats for microbial growth; however, further research should be conducted. The unique substrate amendment (i.e., peatmoss) may have accounted for the deviation in microbial community structures from other substrate treatments. Gonzalez et al. (1986) stated that fungi and actinomycetes are known to grow on lignin-related compounds. Depending on the particular plants responsible for the ultimate cultivation and formation of the peatmoss materials used in this study may have directly influenced its lignin contents. Peat moss materials typically have high lignin composition (Worrall et al., 2017). Bambalov (2007) concluded that the lignin content of peatmoss after the degradation of peat bogs is closely associated with the type of plant material that is degraded.

There were no observable differences among the remainder of microbial communities (arbuscular mycorrhizae, fungi, gram negative, gram positive, protozoa, and eukaryotes) across substrate treatments within irrigation schedules (Table 5; Fig. 5). There appear to be no noticeable separations among substrate treatments (Fig. 5B, C, E, and F). This may be likely due to common pine bark processing procedures (i.e., composting/ageing). Many processors age pine bark to stabilize the material from microbial degradation. Fresh bark decomposes much quicker than aged bark (Fields, 2012) and will generally stabilize after 6 months of aging (Kaderabek, 2017). Aging bark can significantly decrease the rate in nitrogen and carbon depletion through microbial degradation when compared with fresh bark or the early stages of the aging process. The increased proportions of stabilized, aged bark (FB and CTL) may account for few differences in variation among substrate treatments apart from BP. 


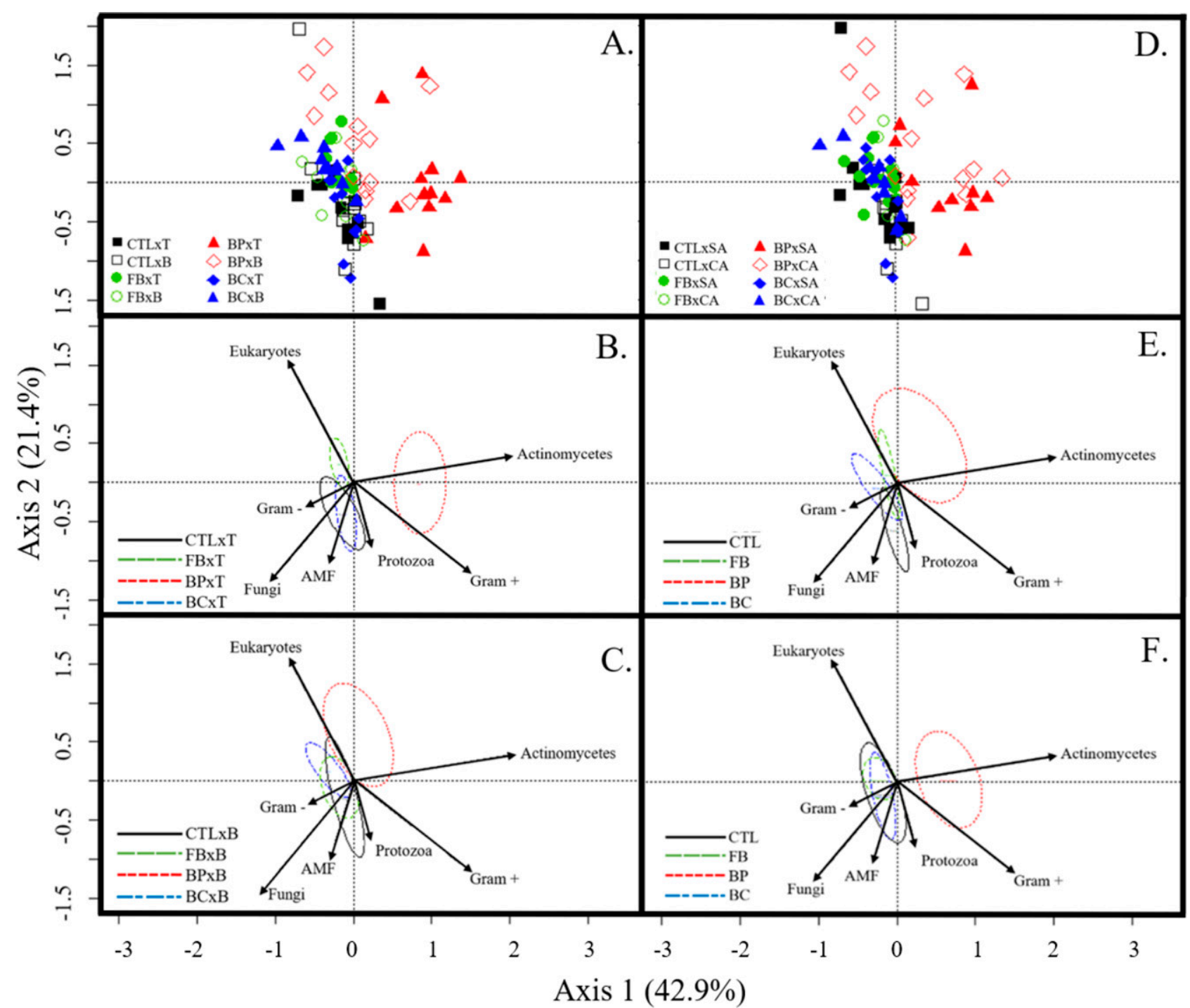

Fig. 5. Relative abundance microbial interaction ordination plots of distance-based analysis derived from fatty acid profiles. Conventional pine bark (CTL), stratified-fine bark (FB), stratified-bark:peat (BP), and stratified-bark:coir (BC). The graphs illustrate the interaction sample distributions between substrate and strata layer (A), ellipses and vectors of the interaction between substrate and upper strata (B), ellipses and vectors of the interaction between substrate and lower strata $(\mathbf{C})$, the interaction sample distributions between substrate and irrigation schedule (D), ellipses and vectors of the interaction between substrate and single application (E), ellipses and vectors of the interaction between substrate and cyclic scheduling $(\mathbf{F})$. Ellipses represent 1 standard error around the centroid for each sampling group. Vectors analyzed were arbuscular mycorrhizae (AMF), fungi, gram negative (Gram-), gram positive $($ Gram +$)$, protozoa, and eukaryotes.

\section{Conclusion}

Traditional bark-based substrates, such as pine bark, tend to have low water-holding capabilities that can lead to nonuniform rewetting patterns and inefficient usage of water resources. Engineering the water dynamics of substrates to reallocate water retention and maximize aeration within the container may lead to improved water resource efficiencies. Substrate stratification encompasses numerous benefits that can be deemed favorable to the nursery industry.

The results herein have demonstrated that fractioning pine bark particles smaller or larger than $6.3 \mathrm{~mm}$ influenced substrate water retention and release properties. Incorporating the substrate amendments peatmoss and coconut coir significantly increased $\mathrm{CC}$ and reduced AS.
Stratified substrates have demonstrated that crop quality and growth can be enhanced by allowing more available water to plant roots in the upper strata. The traditional soilless substrates commonly used by plant nurseries were incapable of maintaining adequate substrate moisture for plant roots until the next subsequent irrigation, which resulted in severe water stresses and death. Plant shoot quality was enhanced by substrate stratification, except in SD, where there were no discernable differences from CTL. There were no observed differences in root:shoot dry weight, $\Delta \mathrm{GI}$, and LAI. Root growth was strongly influenced by a substrate and irrigation interaction, where there were discernible differences among substrate treatments across irrigation schedules.

Foliar nutrient analysis showed minimal differences among foliar macro- and micronutrient concentrations of plants grown within different substrate treatments. There was no detectable substrate effect on pourthrough EC measurements over the course of the study. Nutrient leachate concentrations demonstrated that there were minimal differences among substrate treatments from the initial to near culmination of the study. However, nitrate leachate concentrations within CTL treatments under SA were statistically greater at the end of the study than the beginning. There were few differences observed in microbial communities across substrate treatments, with the exception of BP, which contained greater proportions of actinomycetes.

The results show that because the stratified system holds more water in locations in which water is quickly lost due to gravitational forces or evapotranspiration, possibly more available water was present for root 
Table 5. Relative abundance of microbial communities quantified by fatty acid methyl ester analysis (FAMEs) using gas chromatography. Samples were taken across four substrate treatments: 1) conventional bark (CTL), 2) stratified-fine bark (FB), 3) stratified-bark:peat (BP), and 4) stratified-bark:coir (BC) in the upper and lower strata (top and bottom, respectively), within two irrigation schedules: single application (SA) and cyclic application (CA).

\begin{tabular}{|c|c|c|c|c|c|c|c|c|}
\hline & & $\begin{array}{c}\text { Actinomycetes } \\
(\mathrm{mol} \%)\end{array}$ & $\begin{array}{l}\text { Arbuscular } \\
\text { mycorrhizae } \\
(\mathrm{mol} \%)\end{array}$ & $\begin{array}{c}\text { Fungi } \\
(\mathrm{mol} \%)\end{array}$ & $\begin{array}{c}\text { Gram }(-) \\
\text { negative } \\
(\text { mol \%) }\end{array}$ & $\begin{array}{c}\text { Gram (+) } \\
\text { positive } \\
(\mathrm{mol} \%)\end{array}$ & $\begin{array}{c}\text { Protozoa } \\
(\mathrm{mol} \mathrm{\% )})\end{array}$ & $\begin{array}{c}\text { Eukaryotes } \\
(\mathrm{mol} \%)\end{array}$ \\
\hline \multirow[t]{4}{*}{$\overline{\mathrm{SA}}$} & CTL: Top & $1.20 \mathrm{abc}^{\mathrm{z}}$ & 0.69 & 17.48 & 5.52 & 11.57 & 0.51 & 11.13 \\
\hline & FB: Bottom & $0.68 \mathrm{bc}$ & 0.63 & 19.53 & 6.03 & 9.19 & 1.86 & 12.79 \\
\hline & BP: Top & $1.17 \mathrm{abc}$ & 0.94 & 19.91 & 5.71 & 10.41 & 0.60 & 11.46 \\
\hline & BP: Bottom & $1.20 \mathrm{abc}$ & 0.82 & 19.11 & 5.98 & 9.45 & 0.54 & 13.30 \\
\hline \multirow[t]{6}{*}{$\mathrm{CA}$} & CTL: Top & $1.50 \mathrm{abc}$ & 0.94 & 18.36 & 5.52 & 10.62 & 0.40 & 12.17 \\
\hline & CTL: Bottom & $2.18 \mathrm{ab}$ & 1.02 & 19.55 & 5.87 & 11.18 & 0.83 & 11.61 \\
\hline & FB: Top & $0.74 a b c$ & 0.72 & 22.50 & 5.78 & 8.45 & 0.48 & 13.16 \\
\hline & FB: Bottom & $1.77 \mathrm{abc}$ & 0.77 & 19.31 & 6.28 & 11.96 & 0.58 & 10.60 \\
\hline & BP: Top & $2.29 \mathrm{a}$ & 0.54 & 18.10 & 5.39 & 10.44 & 0.67 & 11.83 \\
\hline & BP: Bottom & $1.73 \mathrm{ab}$ & 0.76 & 18.12 & 5.72 & 10.16 & 0.55 & 12.47 \\
\hline
\end{tabular}

${ }_{\mathrm{z}}$ Letters denote detected differences among means of a full factorial including from four substrates (CTL, FB, BP, and BC) and two irrigations (SA and CA) using Tukey's honestly significant difference test $(\alpha=0.05)$ within columns $\approx 120 \mathrm{~d}$ after initiation. Values with no letters denote no significant difference.

${ }^{\mathrm{y}}$ Measures of overall treatment effects using analysis of variance using a significance level $(\alpha=0.05)$.

utilization, whereas in traditional substrate systems, the upper portion of the substrate profile was too dry for establishing roots. In addition, because drainage is maximized in the lower half of stratified systems, more aeration can possibly occur and the level of a perched water table is likely reduced. However, in traditional substate systems, where perched water tables are likely greater than in stratified systems, ample gas exchange may be compromised, inhibiting plant growth. In doing so, stratified substrates can sustain crop growth until subsequent applications of water are delivered.

\section{Literature Cited}

Altland, J.E., J.C. Locke, and C.R. Krause. 2014. Influence of pine bark particle size and $\mathrm{pH}$ on cation exchange capacity. HortTechnology 24:554-559.

Altland, J.E. and K. Jeong. 2016. Dolomitic lime amendment affects pine bark substrate ph, nutrient availability, and plant growth: A review. HortTechnology 26:565-573.

Altland, J.E., J.S. Owen, B.E. Jackson, and J.S. Fields. 2018. Physical and hydraulic properties of commercial pine-bark substrate products used in production of containerized crops. HortScience 53:1883-1890.

Asiah, M.A., R.I. Mohd, K.Y. Marziah, and M. Shaharuddin. 2004. Physical and chemical properties of coconut coir dust and oil palm empty fruit bunch and the growth of hybrid heat tolerant cauliflower plant. Pertanika, J. Trop. Agr. Sci. 27:121-133.

Asrey, R., S. Kumar, and N.K. Meena. 2018. Influence of water quality on postharvest fruit and vegetable quality, p. 169-187. M.W. Siddiqui (ed.). Preharvest modulation of postharvest fruit and vegetable quality. Academic Press, Cambridge, MA.

Avent, T. 2003. So you want to start a nursery. Timber Press Inc., Portland, OR.
Baker, K.F. 1957. The U.C. system for producing healthy container-grown plants. Ed. California Agric. Expt. Sta. Extension Service Manual 23, Univ. California, College of Agriculture Publication, Berkeley, CA.

Bambalov, N.N. 2007. The lignin content in virgin and cultivated peat soils of Belarussian poles'e. Eurasian Soil Sci. 40:1175-1180.

Barrett, G.E., P.D. Alexander, J.S. Robinson, and N.C. Bragg. 2016. Achieving environmentally sustainable growing media for soilless plant cultivation systems - A review. Scientia Hort. 212:220-234.

Bauters, T.W.J., D.A. DiCarlo, T.S. Steenhuis, and J.Y. Parlange. 2000. Soil water content dependent wetting front characteristics in sands. J. Hydrol. (Amst.) 231:244-254.

Bayer, A., I. Mahbub, M. Chappell, J. Ruter, and M.W. van Iersel. 2013. Water use and growth of Hibiscus acetosella 'Panama Red' grown with a soil moisture sensor-controlled irrigation system. HortScience 48:980-987.

Bayer, A., J. Ruter, and M.W. van Iersel. 2015. Optimizing irrigation and fertilization of Gardenia jasminoides for good growth and minimal leaching. HortScience 50:50994-51001.

Beeson, R.C., Jr. and J. Haydu. 1995. Cyclic microirrigation in container-grown landscape plants improves plant growth and water conservation. J. Amer. Env. Hort. Sci. 13:6-11.

Beeson, R.C., Jr. 2006. Relationship of plant growth and actual evapotranspiration to irrigation frequency based on management allowed deficits for container nursery stock. J. Amer. Soc. Hort. 131:140-148.

Bilderback, T.E. and W.C. Fonteno. 1987. Effects of container geometry and media physical properties on air and water volumes in containers. J. Environ. Hort. 5:180-182.

Bilderback, T.E., J.S. Owen, Jr., J.E. Altland, G.B. Fain, B.E. Jackson, E.D. Riley, H.T. Kraus, and W.C. Fonteno. 2013. Strategies for developing sustainable substrates in nursery crop production. Acta Hort. 1013:43-56.
Blum, A. 1996. Crop responses to drought and the interpretation of adaptation. Plant Growth Regulat. 20:135-148.

Brady, N.C. and R.R. Weil. 1996. The nature and properties of soils. Prentice-Hall, Inc., Upper Saddle River, NJ.

Buamscha, M., J.E. Altland, D.M. Sullivan, D.A Horneck, and J.G. McQueen. 2008. Nitrogen availability in fresh and aged douglas fir bark. HortTechnology 18:619-623.

Cai, X., T. Starman, G. Niu, C. Hall, and L. Lombardini. 2012. Response of selected garden roses to drought stress. HortScience 47:1050-1055.

Calzadilla, A., K. Rehdanz, and R.S.J. Tol. 2010. The economic impact of more sustainable water use in agriculture: A computable general equilibrium analysis. J. Hydrol. 384:292-305.

Caron, J., P.H. Morel, L.M. Rivière. 1999. Aeration in growing media containing large particle size. ISHS Acta Horticulturae. 548:229-234.

Costa, J.M., M.F. Ortuña, and M.M. Chaves. 2007. Deficit irrigation as a strategy to save water: Physiology and potential application to horticulture. J. Integr. Plant Biol. 49:1421-1434.

Davis, C.L., C.J. Donkin, S.A. Hinch, and P. Germishuizen. 1992. The microbiology of pine bark composting: An electron-microscope and physiological study. Bioresource Technol. 40: 195-204.

Dennis, J.H., R.G. Lopez, B.K. Behe, C.R. Hall, C. Yue, and B.L. Campbell. 2010. Sustainable production practices adopted by greenhouse and nursery plant growers. HortScience 45(8):1232-1237.

Dumroese R.K., T.D. Landis, T. Luna. 2012. Raising native plants in nurseries: Basic concepts. Gen. Tech. Rep. RMRS-GTR-274. Fort Collins, CO: U.S. Department of Agriculture, Forest Service, Rocky Mountain Research Station. 84 p.

Evans, M.R., S. Konduru, and R.H. Stamps. 1996. Source variation in physical and chemical properties of coconut coir dust. HortScience 31: 965-967.

Fare, D.C., C.H. Gilliam, G.J. Keever, and J.W. Olive. 1994. Cyclic irrigation reduces container 
leachate nitrate-nitrogen concentration. HortScience 29:1514-1517.

Fereres, E. and M.A. Soriano. 2007. Deficit irrigation for reducing agricultural water use. J. Expt. Bot. 58(2):147-159.

Fields, J.S. 2012. Hydrophysical properties and hydration efficiency of traditional and alternative greenhouse substrate components. North Carolina State University, Raleigh, Master's Thesis.

Fields, J.S., W.C. Fonteno, B.E. Jackson, J.L. Heitman, and J.S. Owen, Jr. 2014a. Hydrophysical properties, moisture retention, and drainage profiles of wood and traditional components for greenhouse substrates. HortScience 49:827-832.

Fields, J.S., W.C. Fonteno, and B.E. Jackson. 2014b. Hydration efficiency of traditional and alternative greenhouse substrate components. HortScience 49:336-342.

Fields, J.S. 2016. Soilless substrate hydrology and subsequent impacts on plant-water relations of containerized crops. Virginia Tech, Blacksburg, PhD Diss.

Fields, J.S., J.S. Owen, Jr., and H. Scoggins. 2017. The influence of substrate hydraulic conductivity of an ornamental container crop grown in suboptimal substrate water potentials. HortScience 52:1419-1428.

Fields, J.S., J.S. Owen, Jr., J.E. Altland, M.W. van Iersel, and B.E. Jackson. 2018. Soilless substrate hydrology can be engineered to influence plant water status for an ornamental containerized crop grown within optimal water potentials. Amer. Soc. Hort. Sci. 143:268-281.

Fields, J.S., J.S. Owen, Jr., and J.E. Altland. 2020. Stratified substrates: A media management strategy for increased resource efficiency. HortScience 55:S399-S400.

Fields, J.S., J.S. Owen Jr., and J.E. Altland. 2021. Substrate stratification: Layering unique substrates within a container increases resource efficiency without impacting growth of shrub rose. Agron. J. 11:1454, https://doi.org/10.3390/ agronomy11081454.

Folger, P. 2017. Drought in the United States: Causes and current understanding. Congressional Research Services. <https://fas.org/sgp/crs/ misc/R43407.pdf>

Fonteno, W.C. 1989. An approach to modeling air and water status of horticultural substrates. Acta Hort. 238:67-74.

Fonteno, W.C. and C.T. Harden. 2010. North Carolina State University Horticultural substrates lab manual. North Carolina State University, Raleigh, NC.

Fromm, J. 2010. Wood formation of trees in relation to potassium and calcium nutrition. Tree Physiol. 30:1140-1147.

Frostegård, A., A. Tunlid, and E. Bååth. 1993. Phospholipid fatty acid composition, biomass, and activity of soil microbial communities from two soil types experimentally exposed to different metals. Appl. Environ. Microbiol. 59:36053617.

Fulcher, A. and T. Fernandez. 2013a. Sustainable nursery irrigation management series: Part I. Water use in nursery production. Bulletin W287, Univ. of Tennessee, Knoxville, TN.

Fulcher, A. and T. Fernandez. 2013b. Sustainable nursery irrigation management series: Part II. Water use in nursery production. Bulletin W279, Univ. of Tennessee, Knoxville, TN.

Fulcher, A., A.V. LeBude, J.S. Owen, Jr., S.A. White, and R.C. Beeson. 2016. The next ten years: Strategic vision of water resources for nursery producers. HortTechnology 26:121-132.

Gómez-Pérez, L., L. Valdez-Aguilar, A. SandovalRangel, A. Benavides-Mendoza, R. Mendoza-
Villarreal, and A. Castillo-González. 2014. Calcium ameliorates the tolerance of Lisianthus [Eustoma grandiflorum (Raf.) Shinn.] to alkalinity in irrigation water. HortScience 49:807-811.

Gonzalez, B., A. Merino, M. Almeida, and R Vicna. 1986. Comparative growth of natural bacterial isolates on various lignin-related compounds. Appl. Environ. Microbiology 52: 1428-1432.

Graves, W.R., M.A. Kroggel, and M.P. Widrlechner. 2002. Photosynthesis and shoot health of 0five birch and four alder taxa after drought and flooding. J. Environ. Hort. 20:36-40.

Gray, E. and J. Merzdorf. 2019. Earth's freshwater future: Extremes of flood and drought - climate change: Vital signs of the planet. NASA, Global Climate Change 23. <https://climate.nasa.gov/ $>$.

Grossnickle, S.C. 2005. Importance of root growth in overcoming planting stress. New For. 30: 273-294.

Gu, M., C.R. Rom, J.A. Robbins, and D.M. Oosterhuis. 2007. Effect of water deficit on gas exchange, osmotic solutes, leaf abscission, and growth of four birch genotypes (Betula L.) under a controlled environment. HortScience 42:1383-1391.

Harris, R.W. 1967. Factors influencing root development of container grown trees. Proc. Int'1. Shade Tree Conf. 43:304-314.

Hillel, D. 2004. Introduction to environmental soil physics. Elsevier Academic Press, San Deigo, CA.

Hoskins, T.C., J.S. Owen, Jr., and A.X. Niemiera. 2014a. Controlled-release fertilizer placement affects the leaching pattern of nutrients from nursery containers during irrigation. HortScience 49:1341-1345.

Hoskins, T.C., J.S. Owen, J.S. Fields, J.E. Altland, Z.M. Easton, and A.X. Niemiera. 2014b. Solute transport through a pine bark-based substrate under saturated and unsaturated conditions. J. Amer. Soc. Hort. Sci. 139:634-641.

Hoskins, T.C., J.S. Owen, and A.X. Niemiera. 2014c. Water movement through a pine-bark substrate during irrigation. HortScience 49: 1432-1436.

Ismail, S.M., K. Ozawa, and N.A. Khondaker. 2007. Influence of single and multiple water application timings on yield and water use efficiency in tomato (var. First Power). Agr. Water Mgt. 95:116-122.

Jackson, B., F. Browder, and R. Wright. 2006. A comparison of nutrient requirements between pine chip and pine bark substrates. Combined Proc. Intl. Plant Prop. Soc. 56:623-626.

Jackson, B.E., R.D. Wright, and J.R. Seiler. 2009a. Changes in chemical and physical properties of pine tree substrate and pine bark during longterm nursery crop production. HortScience 44:791-799.

Jackson, B.E., R.D. Wright, and M.M. Alley. 2009b. Comparison of fertilizer nitrogen availability, nitrogen immobilization, substrate carbon dioxide efflux, and nutrient leaching in peat-lite, pine bark, and pine tree substrates. HortScience 44:781-790.

Jackson, B.E., R.D. Wright, and M.C. Barnes. 2010. Methods of constructing a pine tree substrate from various wood particle sizes, organic amendments, and sand for desired physical properties and plant growth. HortScience 45:103-112.

Jackson, B.E. 2020. The marriage of bark and wood. Nursery Manage. 36(October):10-14

Jahromi, B.N., A. Fulcher, F. Walker, and J. Altland. 2020. Optimizing substrate available water and coir amendment rate in pine bark substrates. Water 12:362.
Kaderabek, L.E. 2017. Effects of aging on the physical, chemical, and hydrologic properties of pine bark substrates. North Carolina State Univ., Raleigh, Thesis

Karam, N.S. 1993. Overhead sprinkler irrigation strategies to reduce water and nitrogen loss from container-grown plants. Virginia Polytechnic Institute and State University, Blacksburg, PhD Diss.

Kingston, P.H., C.F. Scagel, D.R. Bryla, and B. Strik. 2017. Suitability of sphagnum moss, coir, and douglas fir bark as soilless substrates for container production of highbush blueberry. HortScience 52:1692-1699.

Kirda, C. and R. Kanber. 1999. Water, no longer a plentiful resource, should be used sparingly in irrigated agriculture. In: C. Kirda, P. Moutonnet, C. Hera, and D.R. Nielsen (eds.). Crop yield response to deficit irrigation. Kluwer Academic Publishers, Dordrecht, The Netherlands.

Kirkpatrick, C., C.J. Conway, and D. LaRoche 2009. Surface water depletion and riparian birds. Final report submitted to Arizona Game and Fish Department by USGS Arizona Cooperative Fish and Wildlife Research Unit, Tucson, AZ.

Krug, B.A., S.E. Burnett, J.H. Dennis, and R.G. Lopez. 2008. Growers look at operating a sustainable greenhouse. GMPro 28:43-45.

Laczko, E., A. Rudaz, and A. Aragno. 1997. Diversity of anthropogenically influenced or disturbed soil microbial communities, 57-67. In: H. Insam and A. Rangger (eds.). Microbial communities, functional versus structural approaches. SpringerVerlag, Berlin.

Lamack, W.F. and A.X. Niemiera. 1993. Application method affects water application efficiency of spray stake-irrigated containers. HortScience 28:625-627.

LeBude, A.V. and T.E. Bilderback. 2009. The pour-through extraction procedure: A nutrient management tool for nursery crops. North Carolina Coop. Ext. Bul. Ag-171-W.

Lichtenberg, E., J. Majsztrik, and M. Saavoss. 2013. Profitability of sensor-based irrigation in greenhouse and nursery crops. HortTechnology 23:770-774.

Lieth, J.H. and L.R. Oki. 2008. Irrigation in soilless production. Elsevier, San Diego, CA.

Lobet, G., V. Couvreur, F. Meunier, M. Javaux, and X. Draye. 2014. Plant water uptake in drying soils. Plantphsyiol 164:1619-1627.

Londra, P., A. Paraskevopoulou, and M. Psychoyou. 2018. Hydrological behavior of peatand coir-based substrates and their effect on begonia growth. Water 10:722.

Lopez, R.G., Burnett, S.E., Dennis, J.H. \& Krug, B.A. 2008. 8 steps to take to become sustainable. GMPro 28:26-29.

Mack, R., J.S. Owen, Jr., A.X. Niemiera, and J. Latimer. 2017. Virginia nursery and greenhouse grower survey of best management practices. HortTechnology 27:386-392.

Madan, R., C. Pankhurst, B. Hawke, and S. Smith. 2002. Use of fatty acids for identification of AM fungi and estimation of the biomass of AM spores in soil. Soil Biol. Biochem. 34:125-128.

Majsztrik, J.C., R.T. Fernandez, P.R. Fisher, D.R. Hitchcock, J. Lea-Cox, J.S. Owen, Jr., L.R. Oki, and S.A. White. 2017. Water use and treatment in container-grown specialty crop production: A review. Water Air Soil Pollut. 228:151.

Marble, C. and Y. Khamare. 2020. Stratified substrates and strategic fertilizer placement as a weed management tool in container nursery crops. 2020 ASHS Annual Conference Abstract.

Mason, J. 2004. Nursery management. Landlinks Press, Collingwood, Australia. 
Mathers, H.M. and P. Leidenfrost. 1995. Nursery production guide for commercial growers 1995/96 ed. British Columbia Ministry of Agriculture and Food, Victoria, BC, Canada.

Mathers, H.M., T.H. Yeager, and L.T. Case. 2005. Improving irrigation water use in container nurseries. HortTechnology 15:8-12.

Mathers, H.M., S.B. Lowe, C. Scagel, D.K. Struve, and L.T. Case. 2007. Abiotic factors influencing root growth of woody nursery plants in containers. HortTechnology 17:151-162.

Milks, R.R., W.C. Fonteno, and R.A. Larson. 1989. Hydrology of horticultural substrates: II. Predicting physical properties of substrate in containers. J. Amer. Soc. Hort. Sci. 114:53-56.

Million, J.B. and T.H. Yeager. 2015. CIRRIG: Weather-based irrigation management program for container nurseries. HortTechnology 25:528 535.

Million, J.B. and T.H. Yeager. 2020. Leaching fraction-based microirrigation schedule reduced water use but not $\mathrm{N}$ and $\mathrm{P}$ loss during production of a container-grown shrub. HortScience 56:147-153.

Morgan, J. and C. Winstanley. 1997. Microbial biomarkers, p. 331-352. In: J. Elsas, J.K. Jansson, and J.T. Trevors (eds.). Modern soil microbiology. Marcel Dekker, New York.

Morison, J.I., N.R. Baker, P.M. Mullineaux, and W.J. Davies. 2008. Improving water use in crop production. Philos. Trans. R. Soc. Lond. B Biol. Sci. 363:639-658.

Nambuthiri, S., A. Fulcher, A.K. Koeser, R. Geneve, and G. Niu. 2015. Moving toward sustainability with alternative containers for greenhouse and nursery crop production: A review and research update. HortTechnology 25:8-16.

Nzokou, P. and B.M. Cregg. 2010. Growth, biomass, and nitrogen use efficiency of containerized fraser fir (Abies fraseri) as related to irrigation and nitrogen fertilization. HortScience 45:946-951.

Oksanen, J., F.G. Blanchet, M. Friendly, R. Kindt, P. Legendre, D. McGlinn, P.R. Minchin, R.B. O'Hara, G.L. Simson, P. Solymos, M. Henry, H. Stevens, E. Szoecs, and H. Wagner. 2020. vegan: Community Ecology Package ( $\mathrm{R}$ package version 2.5-7). Vienna, Austria: R Foundation for Statistical Computing.

O’Leary, W.M. and S.G. Wilkinson. 1988. Grampositive bacteria, p. 117-185. In: C. Ratledge and S.G. Wilkinson (eds.). Microbial lipids. Academic Press, London.

Owen, J.S. and J.E. Altland. 2008. Container height and douglas fir bark texture affect substrate physical properties. HortScience 43:505-508.

Pancerz, M. and J.E. Altland. 2020. pH buffering in pine bark substrates as a function of particle size. HortScience 55:1817-1821.
Paul, E.A. and F.E. Clark. 1988. Soil microbiology and biochemistry. Academic Press, San Diego, CA.

Pokorny, F.A., P.G. Gibson, and M.G. Dunavent. 1986. Prediction of bulk density of pine bark and/or sand potting media from laboratory analyses of individual components. J. Amer. Soc. Hort. Sci. 111:8-11.

Quideau, S.A., A.C. McIntosh, C.E. Norris, E. Lloret, M.J. Swallow, and K. Hannam. 2016. Extraction and analysis of microbial phospholipid fatty acids in soils. J. Vis. Exp. 114:54360.

Ratledge, C. and S.G. Wilkinson. 1988. Microbial lipids. Academic Press, London.

Raviv, M. and J.H. Lieth. 2008. Soilless culture theory and practice. Elsevier, San Diego, CA.

R Core Team. 2020. R: A language and environment for statistical computing. $\mathrm{R}$ foundation for statistical computing, Vienna, Austria.

Richards, D., M. Lane, and D.V. Beardsell. 1986. The influence of particle-size distribution in pinebark: Sand: Brown coal potting mixes on water supply, aeration and plant growth. Scientia Hort. 29:1-14.

Richards, D.L. and D.W. Reed. 2004. New Guinea impatiens growth response and nutrient release from controlled-release fertilizer in a recirculating subirrigation and top-watering system. HortScience 39:280-286.

Ruter, J.M. 1998. Pot-In-Pot production and cyclic irrigation influence growth and irrigation efficiency of 'Okame' cherries. J. Environ. Hort. $16: 159-162$

Scagel, C.F. 2003. Growth and nutrient use of Ericaceous plants grown in media amended with sphagnum moss peat or coir dust. HortScience 38:46-54.

Steward, D.R. and A.J. Allen. 2016. Peak groundwater depletion in the High Plains Aquifer, projections from 1930 to 2110 . Agr. Waste Manag. 170:36-48.

Taylor, A.J., R. Fernandez, P. Nzokou, and B. Cregg. 2013. Carbon isotope discrimination, gas exchange, and growth of container-grown conifers under cyclic irrigation. HortScience 48:848-854.

Thomas, B.F. and J.S. Famiglietti. 2019. Identifying climate-induced groundwater depletion in grace observations. Sci. Rep. 9:4124.

Tian, W., H. Wang, X. Xiang, R. Wang, and Y. $\mathrm{Xu}$. 2019. Structural variations of bacterial community driven by sphagnum microhabitat differentiation in a subalpine peatland. Front. Microbiol. 10:1661.

Tyler, H.H., S.L. Warren, and T.E. Bilderback. 1996. Cyclic irrigation increases irrigation application efficiency and decreases ammonium losses. J. Environ. Hort. 14:194-198.
U.S. Department of Agriculture. 2019. 2017 Census of Agriculture. USDA, p. 52.

U.S. Department of Agriculture. 2020. 2017 Census of Agriculture, 2019 Census of Horticultural Specialties. USDA, p. 1.

van Iersel, M.W., M. Chappell, and J.D. Lea-Cox. 2013. Sensors for improved efficiency of irrigation in greenhouse and nursery production. HortTechnology 23:735-746.

Wallach, R. 2008. Physical characteristics of soilless media, Elsevier, San Diego, CA.

Warren, S.L. and T.E. Bilderback. 2002. Timing of low pressure irrigation affects plant growth and water utilization efficiency. J. Environ. Hort. 20(3):184-188.

Whitcomb, C.. 1984. Plant production in containers. Lacebark Publications, Stillwater, OK.

White, D., J. Stair, and D. Ringelberg. 1996. Quantitative comparisons of in situ microbial biodiversity by signature biomarker analysis. J. Ind. Microbiol. 17:185-196.

Wilkerson, D.C. 1981. Some physical and chemical properties of pine bark growing medium used as an evaluation of its nutritional status. LSU Historical Dissertations and Theses. 3705.

Witcher, A.L. 2003. Evaluation of fertilizer and irrigation production systems for large nursery containers. Louisiana State University, Baton Rouge, Master's Thesis.

Worrall, F., C.S. Moody, G.D. Clay, T.P. Burt, and R. Rose. 2017. The flux of organic matter through a peatland ecosystem: The role of cellulose, lignin, and their control of the ecosystem oxidation state. J. Geophys. Res. Biogeosci. 122: 1655-1671.

Yeager, T.H., D.C. Fare, J. Lea-Cox, J. Ruter, T.E. Bilderback, C.H. Gilliam, A.X. Niemiera, S.L. Warren, T.E. Whitwell, R.D. Wright, and K.M. Tilt. 2007. Best management practices: Guide for producing container-grown plants. 2nd ed. Southern Nurserymen's Assoc., Marietta, GA.

Yeary, W., A. Fulcher, and B. Leib. 2016. Nursery irrigation: A guide for reducing risk and improving production, Univ. of Tennessee Ext.

Zelles, L. and Q.Y. Bai. 1994. Fatty acid patterns on phospholipids and lipopolysaccharides in environmental samples. Chemosphere 28:391-411.

Zelles, L. 1997. Phospholipid fatty acid profiles in selected members of soil microbial communities. Chemosphere 35:275-294.

Zelles, L. 1999. Fatty acid patterns of phospholipids and lipopolysaccharides in the characterization of microbial communities in soil: A review. Biol. Fertil. Soils 29:111-129.

Zinati, G. 2006. Evaluation of container media and cyclic irrigation on Ilex $\times$ meserveae growth and nutrient concentration in leachates. HortScience 41:977. 